\title{
Deficits in Ventromedial Prefrontal Cortex Group 1 Metabotropic Glutamate Receptor Function Mediate Resistance to Extinction during Protracted Withdrawal from an Extensive History of Cocaine Self-Administration
}

\author{
Osnat Ben-Shahar, Arianne D. Sacramento, Bailey W. Miller, Sierra M. Webb, Melissa G. Wroten, Hannah E. Silva, \\ Amanda L. Caruana, Evan J. Gordon, Kyle L. Ploense, Jennifer Ditzhazy, Tod E. Kippin, and Karen K. Szumlinski \\ Department of Psychological and Brain Sciences and the Neuroscience Research Institute, University of California at Santa Barbara, Santa Barbara, \\ California 93106-9660
}

\begin{abstract}
Anomalies in prefrontal cortex (PFC) function are posited to underpin difficulties in learning to suppress drug-seeking behavior during abstinence. Because group 1 metabotropic glutamate receptors (mGluRs) regulate drug-related learning, we assayed the consequences of extended access to intravenous cocaine $(6 \mathrm{~h} / \mathrm{d} ; 0.25 \mathrm{mg} /$ infusion for $10 \mathrm{~d})$ on the PFC expression of group $1 \mathrm{mGluRs}$ and the relevance of observed changes for cocaine seeking. After protracted withdrawal, cocaine-experienced animals exhibited a time-dependent intensification of cue-induced cocaine-seeking behavior and an impaired extinction of this behavior. These behavioral phenomena were associated with a time-dependent reduction in mGluR1/5 expression within ventromedial PFC (vmPFC) of cocaine-experienced animals exposed to extinction testing but not in untested ones. Interestingly, pharmacological manipulations of vmPFC mGluR1/5 produced no immediate effects on cue-induced cocaine-seeking behavior but produced residual effects on a subsequent test for cocaine seeking. At $3 \mathrm{~d}$ withdrawal, cocaine-experienced rats infused intra-vmPFC with mGluR1/5 antagonists, either before or after an initial test for cocaine seeking, persisted in their cocaine seeking akin to cocaine-experienced rats in protracted withdrawal. Conversely, cocaine-experienced rats infused with an mGluR1/5 agonist before the initial test for cocaine-seeking at $30 \mathrm{~d}$ withdrawal exhibited a facilitation of extinction learning. These data indicate that cue-elicited deficits in vmPFC group 1 mGluR function mediate resistance to extinction during protracted withdrawal from a history of extensive cocaine self-administration and pose pharmacological stimulation of these receptors as a potential approach to facilitate learned suppression of drug-seeking behavior that may aid drug abstinence.
\end{abstract}

\section{Introduction}

In cocaine addicts, the presentation of cues that have been associated with cocaine consumption induces drug craving and may cause relapse to drug use (Childress et al., 1999, 2008; Volkow et al., 1999; Garavan et al., 2000; Goldstein et al., 2009b; O’Brien, 2009). The presentation of such cues to cocaine addicts also results in heightened activation of the medial prefrontal cortex (mPFC) (Grant et al., 1996; Childress et al., 1999, 2008; Volkow et al., 1999; Garavan et al., 2000; Goldstein and Volkow, 2002; but see Bonson et al., 2002), an area important for the inhibition of inappropriate behaviors and for behavioral flexibility as it pertains to the adjustment of a behavior

\footnotetext{
Received Aug. 1, 2012; revised Sept. 28, 2012; accepted Oct. 21, 2012.

Author contributions: 0.B.-S., T.E.K., and K.K.S. designed research; 0.B.-S., A.D.S., B.W.M., S.M.W., M.G.W., H.E.S., A.L.C., E.J.G., K.L.P., J.D., and K.K.S. performed research; 0.B.-S., B.W.M., S.M.W., M.G.W., H.E.S., T.E.K., and K.K.S. analyzed data; 0.B.-S., A.D.S., B.W.M., S.M.W., M.G.W., H.E.S., A.L.C., E.J.G., K.L.P., J.D., T.E.K., and K.K.S. wrote the paper.

This work was funded by National Institutes of Health Grants DA024038 (K.K.S.) and DA027525 (T.E.K.), as well as by grants from the Academic Senate of the University of California at Santa Barbara (K.K.S. and 0.B.S.). We thank Chelsea Simpson for her technical assistance.

Correspondence should be addressed to Dr. Karen K. Szumlinski, Department of Psychological and Brain Sciences, University of California at Santa Barbara, Santa Barbara, CA 93106-9660. E-mail: szumlinski@psych.ucsb.edu.

DOI:10.1523/JNEUROSCI.3710-12.2013

Copyright $\odot 2013$ the authors $\quad 0270-6474 / 13 / 330495-12 \$ 15.00 / 0$
}

according to its consequences (Rolls et al., 1994; Damasio, 1996; Konishi et al., 1998; Clark et al., 2004). Finally, the mPFC exhibits hypofunctionality in cocaine addicts (Volkow et al., 1992, 1993; London et al., 2000; Franklin et al., 2002; Matochik et al., 2003; Goldstein et al., 2009a). These observations are consistent with the hypothesis that excessive cocaine consumption results in neural adaptations within the $\mathrm{mPFC}$ that render the addict especially vulnerable to cue-induced relapse.

Preclinical studies provide additional evidence for the importance of the mPFC for cue-induced cocaine seeking. Cue-induced reinstatement of cocaine-seeking behavior, as well as incubation of craving, are paralleled by mPFC activation (Neisewander et al., 2000; Ciccocioppo et al., 2001; Hamlin et al., 2008; Hearing et al., 2008; Zavala et al., 2008; Koya et al., 2009), and inactivation of this brain area attenuates cue-induced reinstatement (McLaughlin and See, 2003; Fuchs et al., 2005), as well as the incubation of cocaine craving (Koya et al., 2009). More specifically, glutamatergic projections from the $\mathrm{MPFC}$ to the nucleus accumbens are hypothesized to be important for cue-induced reinstatement of cocaine-seeking behavior (Kalivas and O'Brien, 2008; Uys and LaLumiere, 2008; Van den Oever et al., 2010), and chronic cocaine self-administration produces alterations in indices of $\mathrm{mPFC}$ 


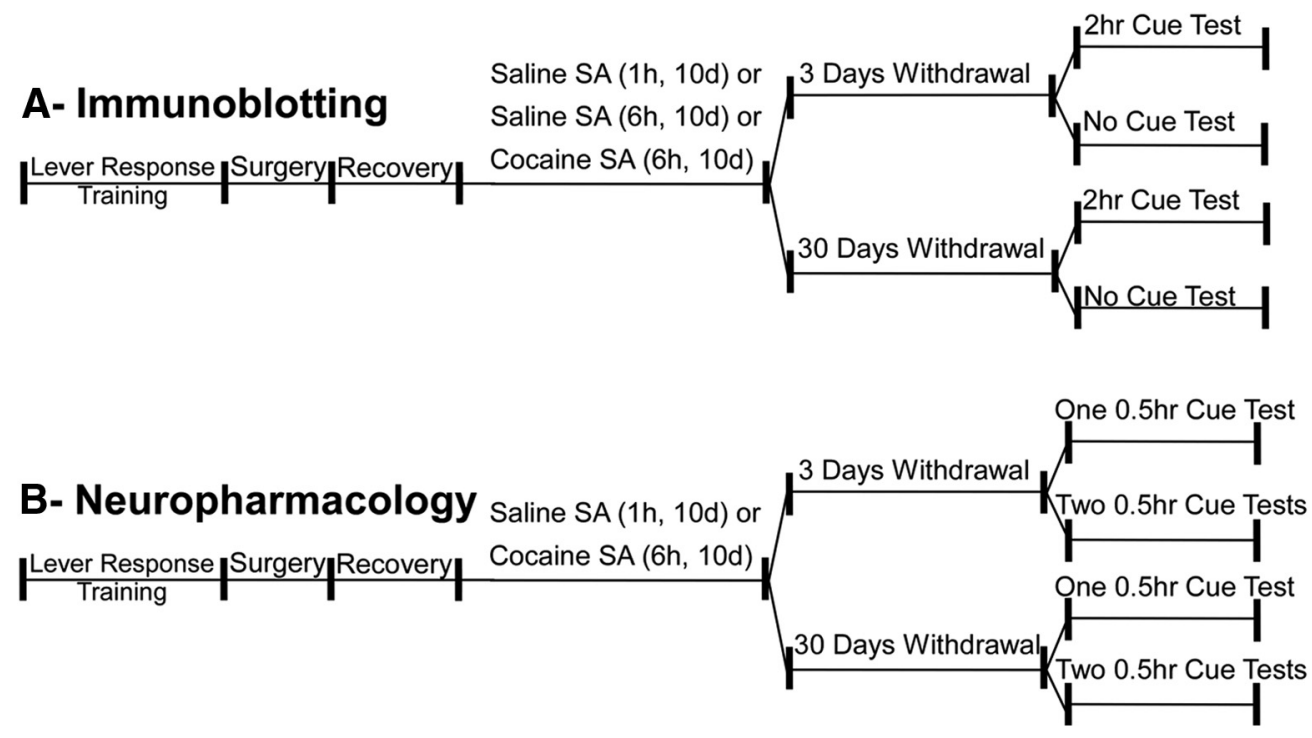

Figure 1. Schema of general procedures and experimental design. $A$, Immunoblotting studies. After self-administration (SA) (10 daily sessions of 1 or $6 \mathrm{~h}$ access to saline or $6 \mathrm{~h}$ access to cocaine), animals were divided to two conditions: 3 or 30 d of withdrawal. After withdrawal, animals were either subjected to a 2 h cue test, immediately killed, and the brains harvested for immunoblotting analysis, or were simply killed (with no other experimental manipulation) with brains harvested for immunoblotting. $\boldsymbol{B}$, Neuropharmacological studies. The procedure was the same as that illustrated in $\boldsymbol{A}$ with one exception: treatment after withdrawal. Here, cohorts of subjects received one or two 30 min cue tests, and brains were harvested for histological verification of microinjector placements.

glutamate function (Robinson et al., 2001; Tang et al., 2004; BenShahar et al., 2009, 2012). One component of the glutamatergic system that was shown to play a critical role in cocaine reinforcement and addiction are the group 1 metabotropic glutamate receptors (subtypes mGluR1 and mGluR5) (Chiamulera et al., 2001; Kenny and Markou, 2004; Olive, 2010). Especially relevant to the current project are demonstrations that systemic administration of the mGluR5 antagonists 2-methyl-6-(phenylethynyl)pyridine hydrochloride (MPEP) or 3-((2-methyl-1,3-thiazol-4-yl)ethynyl)pyridine hydrochloride (MTEP) significantly attenuate cue-induced reinstatement (Bäckström and Hyytiä, 2006; Iso et al., 2006; Kumaresan et al., 2009) and that systemic administration of mGluR5 agonist CDPPB [3-cyano- $N$-(1,3-diphenyl-1 $H$-pyrazol-5-yl)benzamide] facilitated the extinction of cocaine seeking (Cleva et al., 2011). Together, these data suggest that one type of neural adaptation within the mPFC that might develop after excessive cocaine use and be important for cue-induced relapse involves changes in group 1 mGluR function. The present study sought to test this hypothesis by first monitoring changes in the expression group $1 \mathrm{mGluRs}$ within the mPFC after various withdrawal periods and then manipulating such changes to test their functional significance for the incubation of cue-mediated cocaine-seeking behavior (Tran-Nguyen et al., 1998; Grimm et al., 2001, 2002).

\section{Materials and Methods}

Procedure

The general procedure for all experiments described here was identical and consisted of the following steps in chronological order: (1) lever responding (food) training; (2) surgery; (3) self-administration of saline [1 h (Sallh) or $6 \mathrm{~h}$ (Sal6h) daily session, depending on the specific experiment] or cocaine [6 $\mathrm{h}$ (Coc6h) daily sessions] across 10 daily sessions; and then (4) 3 or $30 \mathrm{~d}$ of withdrawal (rats kept in their home cages). After the completion of saline/ cocaine self-administration, the specific procedures varied depending on the particular experiment. For immunoblotting studies, brain tissue was harvested from withdrawn rats at the two different withdrawal time points or animals were subjected to a $2 \mathrm{~h}$ cue test, followed by harvesting of brain tissue. For some neuropharmacological studies, animals received intraventromedial PFC (vmPFC) microinjections, followed by a $30 \mathrm{~min}$ cue test, and then brains were harvested for histological verification of microinjector placements. For other neuropharmacological studies addressing extinction learning, animals received intra-vmPFC or dorsomedial PFC (dmPFC) microinjections, followed by a $30 \mathrm{~min}$ cue test, and then were tested, $24 \mathrm{~h}$ later, in a second $30 \mathrm{~min}$ cue test in the absence of any additional intracranial manipulation, followed by histological verification of microinjector placement. In the following subsections, these various steps are described in detail. For clarity, this general procedure is outlined in Figure 1.

\section{Subjects}

The subjects were male Sprague Dawley rats weighing 275-325 g at the beginning of each experiment and obtained from Charles River Laboratories. Rats were housed in a colony room controlled for temperature $\left(25^{\circ} \mathrm{C}\right)$ and humidity $(71 \%)$, under a $12 \mathrm{~h} \mathrm{light/dark} \mathrm{cycle} \mathrm{(lights} \mathrm{on} \mathrm{at}$ 8:00 P.M.). Animals were given ad libitum access to food and water, except during operant training for food reinforcement (see below, Lever response training). The animals were allowed to acclimate to the colony room for at least $3 \mathrm{~d}$ after arrival. All experimental protocols were consistent with the National Institutes of Health Guide for Care and Use of Laboratory Animals (Publication 80-23, revised 1996) and were reviewed and approved by the University of California, Santa Barbara, Institutional Animal Care and Use Committee.

\section{Lever response training}

To promote lever-pressing behavior for subsequent saline and cocaine reinforcement, rats were first trained to lever press on a fixed-ration 1 (FR1) schedule of food reinforcement (45 mg pellets; Noyes) in soundattenuated operant conditioning chambers $(30 \times 20 \times 24 \mathrm{~cm}$ high; Med Associates) during either a $16 \mathrm{~h}$ overnight training session or daily $1 \mathrm{~h}$ training sessions (depending on availability of our chambers) as described previously by our group (Kerstetter et al., 2008; Ben-Shahar et al., 2009). For this, rats were food deprived for $24 \mathrm{~h}$ before the initiation of training and maintained on a restricted diet for the duration of food training. The operant chambers were equipped with two retractable levers, a stimulus light above each lever, a food pellet dispenser outside the operant box and a food trough between the levers, a house light on the wall opposite to the levers, and a speaker connected to a tone generator (ANL-926; Med Associates). During the session, each lever press on the active lever resulted in delivery of one food pellet. Lever presses on the inactive lever had no programmed consequences. Rats that failed to exhibit the criterion of a minimum of 200 responses on the active lever during the overnight session or a minimum of 100 responses on the active lever during two consecutive $1 \mathrm{~h}$ sessions received additional lever response training sessions until criterion was met. After successful acquisition of lever-pressing behavior (one or two 
overnight sessions; 5-7 d of $1 \mathrm{~h}$ daily sessions), food was available ad libitum for the remainder of the study.

\section{Surgery}

After lever response training, animals underwent surgical procedures to implant chronic intravenous catheters and bilateral guide cannulae into the PFC as described previously by our group (Ben-Shahar et al., 2008, 2009). Under ketamine/xylazine anesthesia (56.25 and $7.5 \mathrm{mg} / \mathrm{kg}$, respectively; Abbott Laboratories), rats were implanted with a chronic Silastic catheter ( $13 \mathrm{~cm}$ long; $0.3 \mathrm{~mm}$ inner diameter, $0.64 \mathrm{~mm}$ outer diameter; Dow Corning) into the right jugular vein. Atropine $(0.04 \mathrm{mg} / \mathrm{kg})$ was administered intramuscularly to minimize respiratory congestion during anesthesia and banamine ( $2 \mathrm{mg} / \mathrm{kg}$; a non-opiate analgesic) was injected subcutaneously to treat postsurgical pain. Each catheter ran subcutaneously around the shoulder to back where it was secured to a threaded 22 gauge metal guide cannula (Plastics One), which emerged from the midline of the animal's back perpendicular to the dorsal surface. An obturator covered the open end of the cannula to protect from contamination and the cannula was held in place via a small swatch of Bard Mesh (C. R. Bard) to which it was cemented. The mesh was, in turn, laid flat subcutaneously on the animal's back.

Immediately after the intravenous catheterization and while still under anesthesia, rats in the behavioral studies were transferred to a stereotaxic apparatus and implanted with 30 gauge guide cannulae (Plastics One) above the vmPFC [anteroposterior (AP), $+2.5 \mathrm{~mm}$; mediolateral (ML), $\pm 1.0 \mathrm{~mm}$; dorsoventral (DV), $-2.0 \mathrm{~mm}$ from bregma] or above the dmPFC (AP, +2.5 $\mathrm{mm} ; \mathrm{ML}, \pm 1.0 \mathrm{~mm} ; \mathrm{DV},-1.0 \mathrm{~mm}$ from bregma), according to the atlas of Paxinos and Watson (2007), using procedures similar to those described previously by our group (Ben-Shahar and Ettenberg, 1998; Zayara et al., 2011). Four small screws and cranioplastic cement secured the guide cannulae to the skull. Stylets (Plastics One) were placed into each cannula to prevent occlusion. All animals were allowed a minimum of $5 \mathrm{~d}$ for recovery, and intravenous catheter patency was maintained by flushing with $0.1 \mathrm{ml}$ of sterile heparin plus timentin/saline (60 IU/ml and $100 \mathrm{mg} / \mathrm{ml}$, respectively) solution each day.

\section{Self-administration training}

After surgery, rats $(n=10-15$ per group per cohort at the start of each experiment) were trained to intravenously self-administer cocaine $(0.25$ $\mathrm{mg} / 0.1 \mathrm{ml} /$ infusion; a generous gift from the National Institute on Drug Abuse) during daily $6 \mathrm{~h}$ sessions on an FR1 schedule of reinforcement. At the start of each session, the rat's catheter was connected to a motorized pump (located outside of the sound-attenuated chamber) via a liquid swivel as described previously (Ben-Shahar et al., 2008; Kerstetter et al., 2008). Active lever presses resulted in a $5 \mathrm{~s}$ activation of the infusion pump and a 20 s presentation of a stimulus complex, consisting of activation of the white stimulus light above the active lever and the tone generator $(78 \mathrm{~dB}, 2 \mathrm{kHz})$, during which responses on the active lever had no consequences. Responses on the inactive lever were recorded but had no programmed consequences. Rats were trained to self-administer cocaine for 10 sessions. To prevent overdose, the number of cocaine infusions permitted during the first $2 \mathrm{~d}$ of training was capped at 100 (day1) and 120 (day2), and rats failing to meet self-administration criterion (minimum of 50 infusions per $6 \mathrm{~h}$ session for the last $3 \mathrm{~d}$ of training) were excluded from the study.

For immunoblotting studies, additional groups of rats were trained to intravenously self-administer saline $(0.1 \mathrm{ml} /$ infusion $)$ during daily 1 or $6 \mathrm{~h}$ sessions ( $n=12$ per control group per cohort at the start of the experiment). Two saline controls groups were included in the immunoblotting study because, for practical reasons, we wanted to replicate the results of previous studies indicating that extended $(6 \mathrm{~h})$ access to intravenous saline does not produce behavioral or protein changes distinct from those observed in animals with short $(1 \mathrm{~h})$ access to intravenous saline (Ben-Shahar et al., 2004). Our behavioral and immunoblotting results confirmed that there were no differences between the two saline controls (see Results), and thus, only $1 \mathrm{~h}$ saline controls were included in the behavioral neuropharmacological studies. All self-administration training and testing occurred during the dark phase of the circadian cycle. After completion of the $10 \mathrm{~d}$ of self-administration training, animals remained in their home cages in the colony room for either 3 or $30 \mathrm{~d}$ withdrawal. At these time points, PFC subregions were harvested from a subset of animals, whereas another subset of animals were tested for cue-elicited cocaine seeking over a $2 \mathrm{~h}$ period, followed by harvesting of PFC subregions.

\section{Tests for cue-elicited cocaine seeking}

With the exception of the one subset of withdrawn rats used for immunoblotting, saline and cocaine self-administering rats were subjected to a test for cue-elicited cocaine seeking under extinction conditions. For the immunoblotting experiments, the cue tests were $2 \mathrm{~h}$ in duration to capture potentially relevant changes in receptor protein expression. To statistically evaluate the presence/absence of response incubation during withdrawal and provide a behavioral correlate for our immunoblotting data, the number of lever responses on the $2 \mathrm{~h}$ cue tests were analyzed using an intravenous treatment (Sal1h, Sal6h, Coc6h) $\times$ withdrawal (3 vs $30 \mathrm{~d}) \times$ lever (active vs inactive) ANOVA. For the behavioral neuropharmacological experiments, the cue tests were $30 \mathrm{~min}$ in duration, as conducted by others (Koya et al., 2009). The cue test conditions were the same regardless of the duration of testing; testing involved tethering the animals and the lever-press response-contingent presentation of the tone-light cue previously paired with saline/cocaine infusions but no saline/cocaine infusions were delivered.

\section{Immunoblotting studies}

Our first immunoblotting study was aimed to investigate the influence of a history of cocaine self-administration experience on the protein expression of mGluR1/5 within PFC subregions at early versus protracted withdrawal. For this study, within each cohort of rats, separate groups of Sal1h, Sal6h, and Coc6h rats underwent a $2 \mathrm{~h}$ cue test session under extinction conditions at either 3 or $30 \mathrm{~d}$ withdrawal ( $n=12$ per group at the start of the experiment) to assay for cue-reinforced lever-pressing behavior. Immediately after completion of this cue test, animals were killed by rapid decapitation. The dmPFC (anterior cingulate and dorsal prelimbic cortices) and vmPFC (ventral prelimbic and infralimbic cortices) were dissected out over ice in a manner identical to that described by others (Ghasemzadeh et al., 2009). The tissue derived from animals in this study was immunoblotted in two separate ways. First, comparisons were made across the tissue from the three different self-administration groups separately for each time point (i.e., Sallh, Sal6h, and Coc6h rats killed at $3 \mathrm{~d}$ withdrawal were compared in one assay, and a parallel assay compared Sallh, Sal6h, and Coc6h rats killed at $30 \mathrm{~d}$ withdrawal in a separate assay). This "single time point" analysis was done to enable a comparison of protein expression between the Sallh and Sal6h rats at each time point, as well as to determine whether or not a history of cocaine self-administration influenced protein expression relative to a history of saline self-administration at that particular withdrawal time point. For these assays, the immunoreactivity of the mGluR1 and mGluR5 bands from the Sal6h and Coc6h animals was normalized to the average of that for the Sallh animals run on the corresponding gel ( $n=4-5$ per gel), and the data were expressed as a percentage of that averaged Sall $\mathrm{h}$ signal for each gel. The data for the 3 and $30 \mathrm{~d}$ assays were analyzed separately using an univariate ANOVA across the three different self-administration groups to determine the presence/absence of a cocaine effect.

The next analysis examined for proteomic correlates of the increased lever pressing exhibited by both saline and cocaine self-administering animals at $30 \mathrm{~d}$ of withdrawal, by comparing tissue from the Sal6h and Coc6h animals killed at both withdrawal time points on the same gel. For this "time course" assay, the immunoreactivity of the mGluR1 and mGluR5 bands were normalized to the average of the Sal6h-3d withdrawal group run on the corresponding gel ( $n=3-4$ per gel), and the data were expressed as a percentage of that averaged signal for each gel. The data were analyzed using orthogonal comparisons, within each selfadministration group, to determine the presence/absence of timedependent changes in protein expression.

A second, follow-up, study assayed vmPFC and dmPFC tissue from Sall h and Coc6h rats, killed at 3 versus $30 \mathrm{~d}$ withdrawal, in the absence of any cue testing. This study was conducted to determine the extent to which our cocaine-induced changes in mGluR1/5 protein expression reflected alterations in the basal expression pattern of these receptors or some interaction between cocaine experience and the cue-reinforced 
testing conditions of our animals. The data analysis for this study was identical to that used for the time course study above.

The immunoblotting procedures for detection of total mGluR1 and mGluR5 levels in brain tissue homogenate were identical to those described recently by our group (Cozzoli et al., 2009, 2012; Goulding et al., 2011). In brief, tissue was homogenized in a solution consisting of $0.32 \mathrm{M}$ sucrose, $2 \mathrm{~mm}$ EDTA, $1 \% \mathrm{w} / \mathrm{v}$ sodium dodecyl sulfate, $50 \mu \mathrm{M}$ phenylmethylsulfonyl fluoride, and $1 \mu \mathrm{g} / \mathrm{ml}$ leupeptin, $\mathrm{pH} 7.2$, and $1 \mathrm{~mm}$ sodium fluoride, $50 \mathrm{~mm}$ sodium pyrophosphate, $20 \mathrm{~mm}$ 2-glycerol phosphate, $1 \mathrm{~mm}$ p-nitrophenyl phosphate, $1 \mathrm{~mm}$ orthovanadate, and 2 $\mu \mathrm{M}$ microcystin LR were included to inhibit phosphatases. After centrifugation at $10,000 \times g$ for $20 \mathrm{~min}$, the supernatant of the homogenates were quantified for protein content using the Bio-Rad DC protein assay and stored at $-80^{\circ} \mathrm{C}$. Protein samples $(20 \mu \mathrm{g} /$ lane $)$ were subjected to SDS-PAGE on Tris-acetate gradient gels (3-8\%) (Invitrogen). Wet polyvinylidene difluoride (Bio-Rad) membrane transfer was used, and membranes were preblocked with PBS containing $0.1 \%(\mathrm{v} / \mathrm{v})$ Tween 20 and $5 \%(\mathrm{w} / \mathrm{v})$ nonfat dried milk powder for a minimum of $2 \mathrm{~h}$ before overnight incubation with primary antibody. An anti-mGluR5 rabbit polyclonal antibody (1:1000 dilution; Millipore) and an anti-mGluR1a mouse polyclonal antibody (1:500 dilution; Millipore) were used for receptor detection. A rabbit primary anti-calnexin antibody (1:1000 dilution; Stressgen) was used as a control to ensure even protein loading and transfer. Membranes were washed, incubated with horseradish peroxidase-conjugated goat anti-rabbit secondary antibody (1:5000-1:10,000 dilution; Millipore) or anti-mouse secondary antibody (1:10,000; Jackson ImmunoResearch) for $90 \mathrm{~min}$, and washed again, and immunoreactive bands were detected by enhanced chemiluminescence using either ECL Plus (GE Healthcare) or Pierce SuperSignal West Femto (Thermo Fisher Scientific). NIH Image J was used to quantify immunoreactivity levels.

\section{Behavioral neuropharmacological studies}

Intra-vmPFC delivery of group $1 \mathrm{mGluR}$ compounds: acute effects on drug seeking. A series of behavioral neuropharmacological experiments were conducted to determine the functional relevance of reduced vmPFC group 1 mGluR expression (see Figs. 2, 3) for the time-dependent increase in cueseeking behavior during withdrawal (see Fig. 2A). For these experiments, Sal1h and Coc6h animals were trained to self-administer for $10 \mathrm{~d}$ and were then bilaterally infused intra-vmPFC with compounds targeting group 1 mGluRs immediately before cue testing using microinjection procedures similar to those described previously (Ben-Shahar and Ettenberg, 1998; Zayara et al., 2011; Ben-Shahar et al., 2012). It was hypothesized that, if the reduction in vmPFC group $1 \mathrm{mGluR}$ expression observed at $30 \mathrm{~d}$ withdrawal mediated the time-dependent increase in lever pressing, then mimicking this reduction earlier in withdrawal should potentiate cocaine-seeking behavior (i.e., render a 3-d-withdrawn animal more similar to a $30-d-$ withdrawn animal). Conversely, hyperstimulating these receptors later in withdrawal should attenuate the heightened cocaine-seeking behavior (i.e., render a 30-d-withdrawn animals more similar to a 3-d-withdrawn animal). To test this hypothesis with respect to mGluR5, groups of 3-dwithdrawn saline and cocaine self-administering rats $(n=5-8$ for saline animals and $n>10$ for cocaine animals at the outset of experiment/ replicate) were infused at $0.5 \mu \mathrm{l} / \mathrm{min}$ with the selective mGluR5 antagonists MPEP ( $3 \mu \mathrm{g} / \mathrm{side}$; Sigma-Aldrich) or MTEP ( $3 \mu \mathrm{g} / \mathrm{side}$; Tocris Bioscience). A parallel study assayed the effects of the selective mGluR1 antagonist JNJ 16259685 [(3,4-dihydro-2 H-pyrano[2,3-b]quinolin-7yl)-(cis-4-methoxycyclohexyl)-methanone] (30 ng/side; Tocris Bioscience). To test the converse hypothesis, groups of 30-d-withdrawn saline or cocaine self-administering rats $(n>8$ per group per replicate) were infused with the mGluR1/5 agonist (S)-3,5-dihydroxyphenylglycine (DHPG) (27.5 ng/side; Tocris Bioscience). The antagonist doses were selected based on published reports indicating an attenuation of drugtaking or drug-seeking behaviors when microinjected into the brain in doses at, or lower than, the doses used in the present studies (Bäckström and Hyytiä, 2007; Cozzoli et al., 2009, 2012; Gass and Olive, 2009a; Kumaresan et al., 2009; Xie et al., 2010, 2012). The dose of DHPG was selected because it elicits a marked rise in locomotor activity and glutamate release when infused into brain (Swanson and Kalivas, 2000; Swanson et al., 2001; Szumlinski et al., 2004; Melendez et al., 2005). Injectors (projecting $2 \mathrm{~mm}$ below the tip of the guide cannulae) were left in place for $1 \mathrm{~min}$ after infusion, and then animals were tested for cue-maintained leverpressing behavior in a $30 \mathrm{~min}$ test immediately after the intracranial injection. Control animals received intra-vmPFC infusions of $0.1 \%$ DMSO vehicle (VEH) (for JNJ 16259585) or water (for MPEP, MTEP, and DHPG). The data for this reiteration of the antagonist study were analyzed using an intravenous (saline vs cocaine) $\times$ intracranial $(V E H, M P E P$, MTEP, JNJ 16259685) ANOVA. Because only cocaine-experienced animals were assayed in this reiteration of the DHPG study, the data were analyzed using $t$ tests across the intracranial factor. $\alpha=0.05$ for all analyses.

Intra-vmPFC infusion of group 1 mGluR compounds: residual effects on drug seeking. We next tested the possibility that the reduction in vmPFC group $1 \mathrm{mGluR}$ expression observed at $30 \mathrm{~d}$ withdrawal from cocaine self-administration (see Figs. 2D, 3A) might render an animal more resistant to extinction if tested repeatedly. The following was done to test this hypothesis: (1) animals in the acute MTEP experiment were subjected to a second drug-seeking test (day 4 of withdrawal) in the absence of any additional intracranial manipulations; (2) the JNJ 16259585 study was replicated in a separate group of animals, which were tested again for effects of vmPFC mGluR1 blockade on day 3 of withdrawal, followed by a second cue test in the absence of any additional pretreatment on day 4 of withdrawal; and (3) the DHPG was replicated in a separate group of animals, which were tested again for effects of vmPFC group $1 \mathrm{mGluR}$ stimulation on day 30 of withdrawal, followed by a second cue test in the absence of any additional pretreatment on day 31 of withdrawal. To determine whether or not the effects of vmPFC group 1 mGluR antagonism on behavior on the second cue test reflected an impairment in operant learning during the first cue-reinforced test session or an impairment in memory consolidation post session, additional cocaine-experienced rats were infused intra-vmPFC with $30 \mathrm{ng} / \mathrm{side}$ JNJ 16259585 immediately after the first test session on day 3 of withdrawal and then tested subsequently for cue-induced lever-pressing behavior the next day in the absence of any additional intracranial manipulation. Finally, to confirm that the behavioral effects that we observed resulted from manipulating group $1 \mathrm{mGluR}$ signaling specifically within the ventral region of the medial PFC, additional groups of Coc6h rats were infused intra-dmPFC (injectors projecting $1 \mathrm{~mm}$ below the tip of the guide cannulae; see Fig. 6) with $30 \mathrm{ng} /$ side JNJ 16259585 or VEH immediately before a test for cue seeking at $3 \mathrm{~d}$ withdrawal, followed by a second cue in the absence of any additional pretreatment on day 4 of withdrawal. The data from these neuropharmacological studies were analyzed initially using an intravenous (saline vs cocaine) $\times$ intracranial (VEH, MTEP, JNJ 16259685 or VEH, DHPG) $\times$ test (test 1 vs test 2) ANOVA (results not reported). In all cases, we observed significant three-way interactions $(p<0.05)$, and thus, the data were deconstructed first along the intravenous factor and analyzed using an intracranial $\times$ test ANOVA to determine whether or not intra-PFC manipulations depended on the drug experience of the animal. To statistically confirm the presence/absence of extinction, significant intracranial $\times$ test interactions were then deconstructed along the intracranial factor and analyzed using a repeated-measures ANOVA across the two cue test sessions ( $\alpha=0.05$ for all analyses). A significant reduction in lever responding from test 1 to test 2 indicated the presence of extinction, whereas a lack of statistical differences were interpreted to reflect an extinction impairment.

\section{Histology}

After the completion of all behavioral pharmacological experiments, animals were killed for histological verification of microinjector placement within the vmPFC or dmPFC. Only animals exhibiting correct placement within ventral prelimbic or within the infralimbic cortices were included in the statistical analyses of the vmPFC neuropharmacological data. Only animals exhibiting correct placement within the dorsal prelimbic or within the anterior cingulate were included in the statistical analyses of the dmPFC neuropharmacological data. Examples of microinjector tip placements from several of the experiments in this study are included in Figure 6. For the most part, two to three animals per group were excluded from the statistical analyses of the behavioral data as a result of misplaced microinjection sites or occlusion of the guide cannulae, and the final 
A
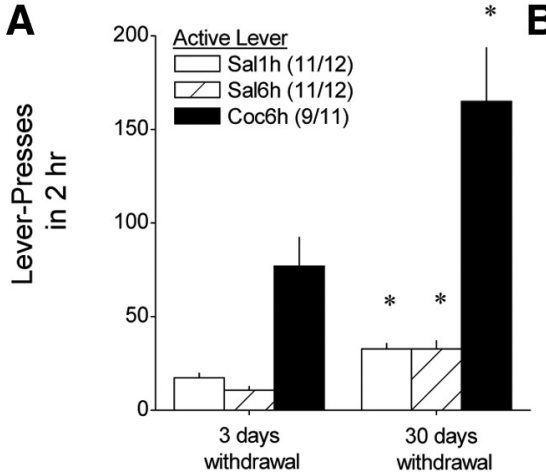

C
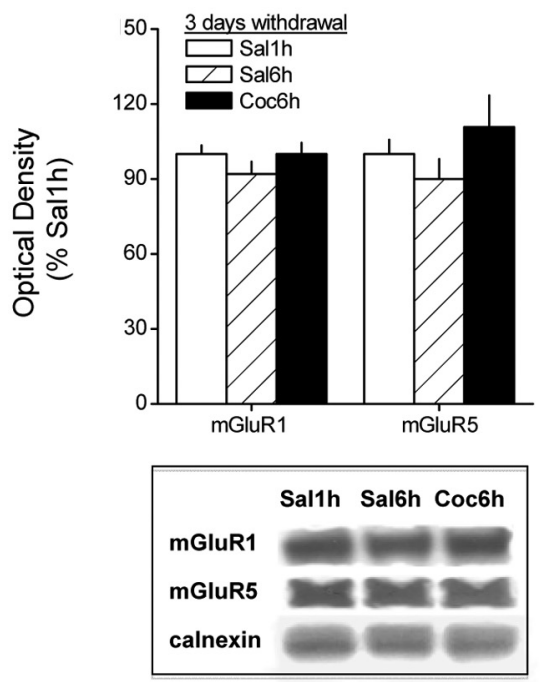

\section{dmPFC}

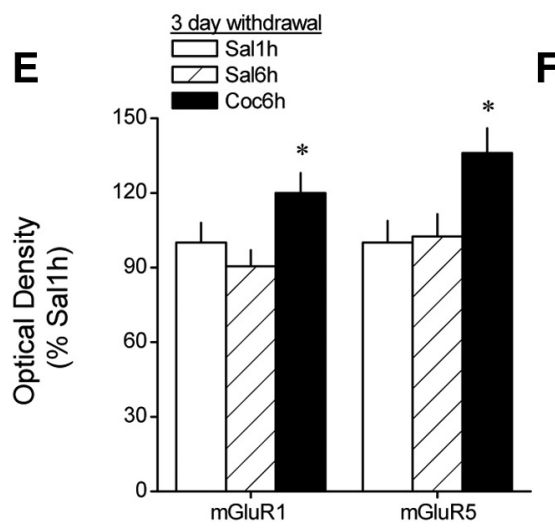

$\mathbf{F}$
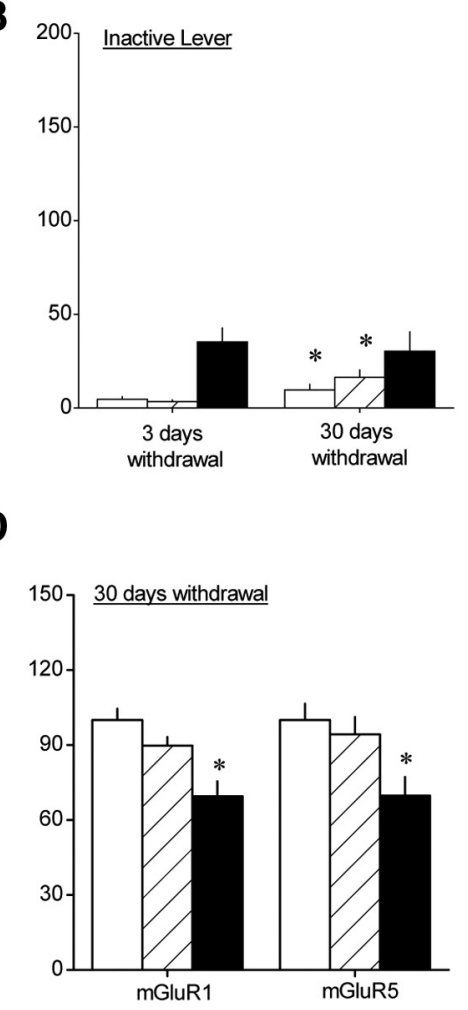

D

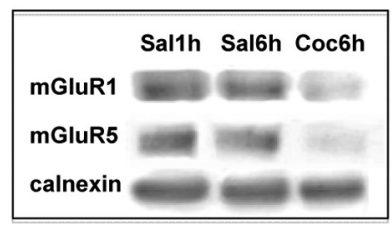

30 days withdrawal

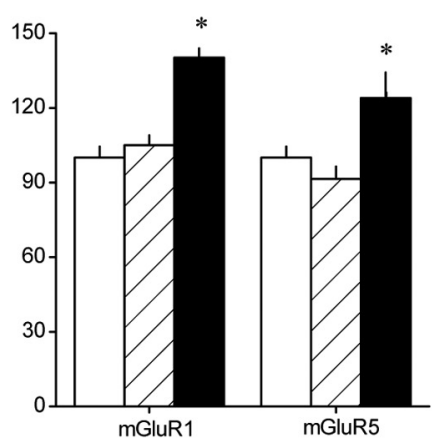

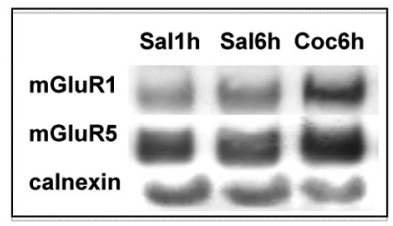

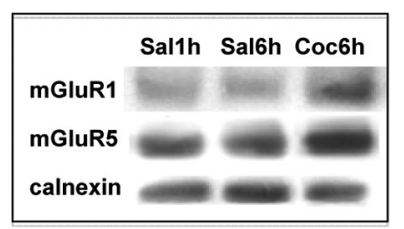

Figure 2. Protracted withdrawal from self-administered cocaine results in increased reinforced responding concomitant with a reduction in vmPFC group $1 \mathrm{mGluR}$ expression. Summary of the total number of active $(\boldsymbol{A})$ and inactive $(\boldsymbol{B})$ lever presses emitted by animals with a $10 \mathrm{~d}$ history of extended access (6h/d) to either cocaine (Coc6h) or saline (Sal6h) and by animals with an equivalent history of limited access $(1 \mathrm{~h} / \mathrm{d})$ to saline (Sal1h) on a $2 \mathrm{~h}$ test in which each active lever press resulted in the presentation of the tone-light stimulus complex previously paired with saline/cocaine infusion but no saline/cocaine delivery. Tests were conducted in separate groups of animals at either 3 or $30 \mathrm{~d}$ withdrawal from saline/cocaine self-administration, and sample sizes ranged from sample sizes used in the statistical analyses of the data are indicated in the appropriate figure or table legend.

\section{Results}

Time-dependent intensification of cueinduced drug seeking occurs after protracted withdrawal only in cocaine self-administering animals

An analysis of the behavior exhibited by our three intravenous treatment groups during a $2 \mathrm{~h}$ test for cue-reinforced behavior conducted under extinction conditions at 3 versus $30 \mathrm{~d}$ withdrawal revealed a significant intravenous treatment (Sallh, Sal6h, Coc6h) $\times$ withdrawal (3 vs $30 \mathrm{~d}) \times$ lever (active vs inactive) interaction $\left(F_{(2,58)}=\right.$ $12.09, p<0.0001)$. Animals with a $10 \mathrm{~d}$ history of extended-access intravenous cocaine self-administration (Coc6h) exhibited a time-dependent increase $(\sim 50 \%)$ in the number of active lever presses emitted for the contingent presentation of the tonelight stimulus complex previously paired with cocaine delivery when tested in the absence of additional cocaine delivery (Fig. $2 A$ ), and there was no concurrent change in the number of inactive lever presses (Fig. $2 B)$ (withdrawal $\times$ lever ANOVA, $F_{(1,16)}=$ $12.55, p=0.003$; for active lever, $F_{(1,16)}=$ $5.29, p=0.04$; for inactive lever, $p=0.72$ ). In addition, because no differences were observed in self-administration behavior during training, between the Coc6h groups tested (and killed) at the different withdrawal time points, the time-dependent increase in cocaine-seeking behavior could not be explained by group differences in cocaine intake or behavioral responding for drug (Table 1). As expected, animals with a history of either brief or extended access to intravenous saline (respectively, Sallh and Sal6h) exhibited significantly lower levels of active lever pressing than cocaine selfadministering animals during both self-administration training (Table 1) and cue testing (Fig. 2). Importantly, in contrast to the cocaine groups, saline groups exhibited a time-dependent increase in responding on both active and inactive levers (for Sallh:

\section{$\leftarrow$}

9 to 12 per group per withdrawal time point. Immediately after completion of behavioral testing, the $\mathrm{dmPFC}$ and vmPFC were dissected out and immunoblotting conducted for mGluR1 and mGluR5. Group differences in vmPFC receptor expression were not observed when assayed at $3 \mathrm{~d}$ withdrawal $(C)$, but $\mathrm{Coc} 6 \mathrm{~h}$ rats exhibited reduced $\mathrm{mGluR} 1 / 5$ when assayed at $30 \mathrm{~d}$ withdrawal (D). In contrast, immunoblotting on dmPFC of these same animals revealed elevated receptor levels in Coc 6 h animals at both 3 and $30 \mathrm{~d}$ withdrawal $(\boldsymbol{E}$ and $\boldsymbol{F}$, respectively). Sample sizes are indicated in $\boldsymbol{A}$ ( $3 \mathrm{~d} / 30 \mathrm{~d}$ withdrawal). For $\boldsymbol{A},{ }^{*} p<0.05$ versus respective data at $3 \mathrm{~d}$ withdrawal. For $\boldsymbol{B}-\boldsymbol{F},{ }^{*} p<0.05$ versus respective Sal $1 \mathrm{~h}$ group. 
Table 1. Comparison of the number of active and inactive lever presses, as well as the number of infusions earned, by animals with extended access to cocaine ( $6 \mathrm{~h} / \mathrm{d}$; Coc $6 \mathrm{~h}$ ) or to saline (Sal6h) and by animals with brief access to saline (1 h/d; Sal1 $\mathrm{h}$ ) during the last $3 \mathrm{~d}$ of self-administration training before being tested for cue-reinforced behavior and tissue harvest for immunoblotting at 3 and $30 \mathrm{~d}$ withdrawal

\begin{tabular}{|c|c|c|c|c|c|c|}
\hline \multirow[b]{2}{*}{ Intravenous treatment } & \multicolumn{2}{|c|}{ Active lever presses } & \multicolumn{2}{|c|}{ Inactive lever presses } & \multicolumn{2}{|l|}{ Infusions } \\
\hline & $3 d$ & $30 d$ & $3 d$ & $30 d$ & $3 d$ & $30 d$ \\
\hline Sal1h & $5.3 \pm 1.0(11)$ & $16.4 \pm 3.4(12)$ & $1.8 \pm 07$ & $2.9 \pm 0.7$ & $3.2 \pm 0.5$ & $8.6 \pm 1.4$ \\
\hline Sal6h & $9.4 \pm 2.6(11)$ & $16.7 \pm 2.9(12)$ & $4.1 \pm 1.4$ & $5.2 \pm 1.9$ & $7.8 \pm 2.2$ & $11.6 \pm 2.1$ \\
\hline Coc6h & $158 \pm 12(7)$ & $139.6 \pm 13.4(10)$ & $3.7 \pm 1.4$ & $5.7 \pm 2.8$ & $125.3 \pm 12.4$ & $121.3 \pm 8.9$ \\
\hline
\end{tabular}

No differences were observed between behavior of animals tested at the 3 versus $30 \mathrm{~d}$ time point within any of the intravenous treatment groups as revealed by no significant main effect of, or interactions with, the withdrawal factor as determined by three-way ANOVA (for active vs inactive lever presses) or two-way ANOVA (for infusions). Numbers in parentheses indicate the final sample sizes used in the statistical analyses of these data.

withdrawal effect, $F_{(1,21)}=16.93, p<0.0001$; withdrawal $\times$ lever, $p=0.4$; for Sal6h: withdrawal $\times$ lever, $F_{(1,21)}=8.21, p=0.009$; one-way ANOVA for active lever, $F_{(1,21)}=19.40, p<0.0001$; for inactive lever, $\left.F_{(1,21)}=4.11, p=0.05\right)$.

Cue-induced cocaine seeking produces subregionally distinct and time-dependent changes in PFC group $1 \mathrm{mGluR}$ expression during withdrawal

We next used conventional immunoblotting strategies to relate the time-dependent increase in cue-reinforced responding to the levels of mGluR1 and mGluR5 within PFC subregions. A comparison of vmPFC receptor levels between Sallh, Sal6h, and Coc6h animals failed to indicate group differences for any protein when animals were killed immediately after the $2 \mathrm{~h}$ test session at $3 \mathrm{~d}$ withdrawal (Fig. $2 C$; one-way ANOVAs, $p$ values $>0.05$ ); however, vmPFC levels of both receptors were reduced in Coc6h rats, relative to both saline groups, when animals were killed after testing at $30 \mathrm{~d}$ withdrawal (Fig. 2D) (mGluR1, $F_{(2,33)}=13.78, p<0.0001$; mGluR5, $F_{(2,33)}=5.74, p=0.008 ;$ LSD post hoc tests, $\left.p<0.05\right)$. Because these data suggested a time-dependent decrease in vmPFC mGluR1/5 levels selectively in animals with a history of cocaine selfadministration, as well as no differences between the saline groups $(p>0.05)$, we conducted a second round of immunoblotting to directly compare for changes in protein expression after cue testing at 3 versus $30 \mathrm{~d}$ in Sal6h and Coc6h animals (Fig. 3). Orthogonal comparisons between the two withdrawal time points indicated no change in vmPFC mGluR1/5 expression in Sal6h rats ( $t$ tests, $p>$ $0.05)$, whereas the levels of both receptors were significantly lower within the vmPFC at the 30 versus $3 \mathrm{~d}$ time point in Coc6h animals (Fig. $3 A)\left(\mathrm{mGluR} 1, t_{(16)}=2.61, p=0.02\right.$; mGluR5, $t_{(16)}=2.20, p=$ $0.05)$. Interestingly, the influence of cocaine experience and withdrawal on vmPFC mGluR1/5 expression appeared to depend on the test history of the subjects because no group differences in vmPFC receptor expression were observed when protein was analyzed in test-naive rats (Fig. $3 B$; $t$ tests, all $p$ values $>0.05$ ). Thus, the opportunity to engage in cue-reinforced behavior after protracted cocaine withdrawal, and not cocaine withdrawal per se, reduced vmPFC group $1 \mathrm{mGluR}$ expression.

In contrast to the vmPFC, dmPFC levels of mGluR1 and mGluR5 were elevated in Coc6h animals relative to both saline self-administration groups at both $3 \mathrm{~d}$ (Fig. $2 E$ ) (mGluR1, $F_{(2,29)}$ $=3.64, p=0.04$; mGluR5, $F_{(2,29)}=4.23, p=0.03$; LSD post hoc tests) and $30 \mathrm{~d}$ (Fig. $2 F$ ) (mGluR1, $F_{(2,32)}=27.98, p<0.0001$; mGluR5, $F_{(2,32)}=5.83, p=0.007$; LSD post hoc tests) withdrawal. A direct comparison of dmPFC tissue from Sal6h rats across both withdrawal time points (Fig. $3 C$ ) revealed no time-dependent changes in mGluR5, but a significant time-dependent reduction in mGluR1 $\left(t_{(21)}=2.19, p=0.04\right)$. No time-dependent changes in $\mathrm{dmPFC}$ receptor expression were apparent in cocaineexperienced animals ( $t$ test, $p<0.05$ ), despite their obvious increase in mGluR1/5 expression relative to saline-experienced animals. Although there was a trend for test-naive, cocaineexperienced animals to exhibit elevated dmPFC mGluR1 expression at both withdrawal time points, group differences in basal mGluR1 or mGluR5 expression were not statistically reliable (Fig. $3 D$; $p$ values $>0.05$ ).

\section{Intra-vmPFC pharmacological manipulations of group 1 mGluR function do not acutely affect cue-induced seeking behavior during withdrawal}

The average number of infusions earned across the last three self-administration sessions were similar in the different intravmPFC treatment groups (Table 2; $p$ values $>0.05$ ). Although an intra-vmPFC infusion of the mGluRla antagonist JNJ 16259685 appeared to increase the number of active lever presses emitted by cocaine rats, the results of the statistical analysis failed to indicate any significant acute effects of our various intra-vmPFC pretreatments on the behavior of either Sallh (Table 3) or Coc6h (Fig. $4 A$ ) animals when tested for cue-reinforced responding at $3 \mathrm{~d}$ withdrawal (intravenous effect, $F_{(1,114)}=128.02, p<0.0001$; intracranial effect and intracranial $\times$ intravenous interaction, $p$ values $>0.15$ ). In addition, we failed to observe any influence of our intra-vmPFC pretreatments on the number of inactive lever presses emitted during this test session (total inactive lever presses in $30 \mathrm{~min}: \mathrm{VEH}, 5.3 \pm 1.7$; MPEP, $4.8 \pm 1.2$; MTEP, $8.4 \pm$ 2.8; JNJ 16259685, $3.6 \pm 1.0$; one-way ANOVA, $p=0.36$ ).

Similarly, the data from a study using only cocaineexperienced animals also failed to indicate any significant effect of an intra-vmPFC infusion of the group $1 \mathrm{mGluR}$ agonist DHPG on lever pressing on a test conducted at $30 \mathrm{~d}$ withdrawal (Fig. $4 B$ ) ( $t$ test, $p>0.20)$.

\section{vmPFC group $1 \mathrm{mGluR}$ blockade impairs extinction learning} during short-term withdrawal from cocaine

To determine whether the reduction in vmPFC group $1 \mathrm{mGluR}$ expression observed at $30 \mathrm{~d}$ withdrawal in Coc6h animals tested for cue-reinforced behavior relates to impaired extinction learning in these animals, we assayed for residual effects of vmPFC group $1 \mathrm{mGluR}$ blockade either before or after the initial test of cue-reinforced behavior (without additional pharmacological manipulation) $24 \mathrm{~h}$ later. As was the case for the initial studies, there were no significant differences regarding the saline/cocaine intake of the animals during the last $3 \mathrm{~d}$ of self-administration training between the different intracranial treatment groups before testing (Table 2 ; all $p$ values $>0.05$ ).

As was observed previously, manipulations of vmPFC group 1 mGluRs failed to influence the behavior of saline-experienced animals on either test, although all saline groups exhibited greater lever-pressing behavior on the second test, in the absence of intracranial microinjection (Table 3) (test effect, $F_{(1,27)}=19.8, p<$ 0.0001 ; all other $p$ values $>0.50)$. A comparison of the behavior of cocaine-experienced rats revealed that the change in behavior 

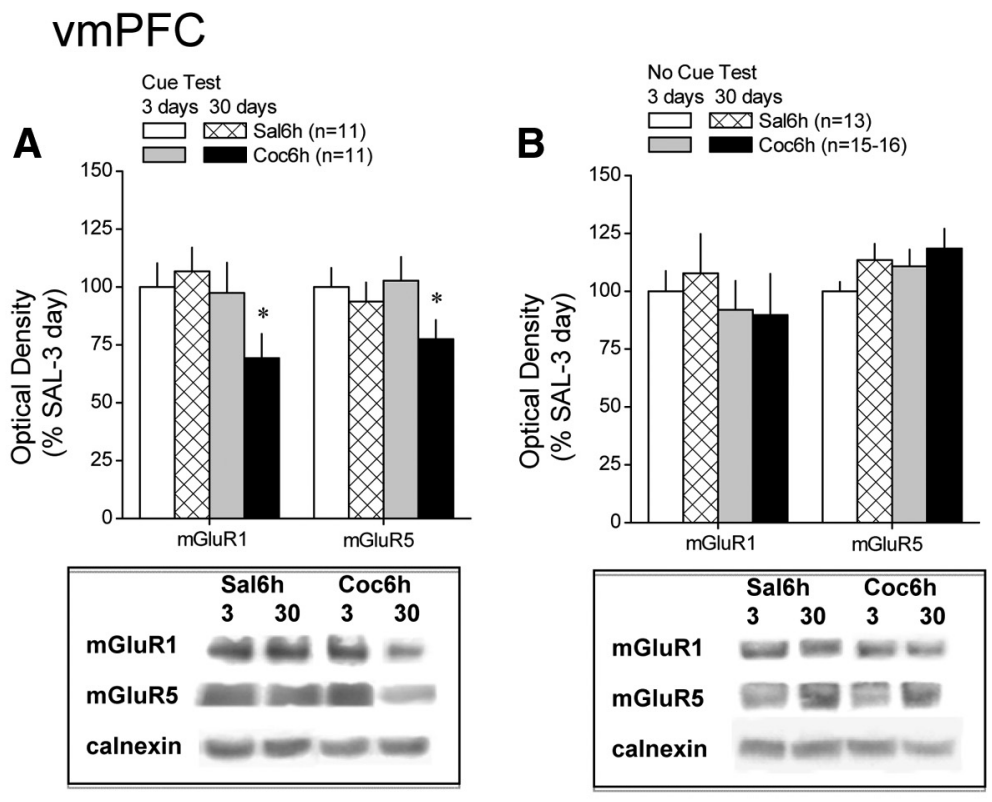

\section{dmPFC}

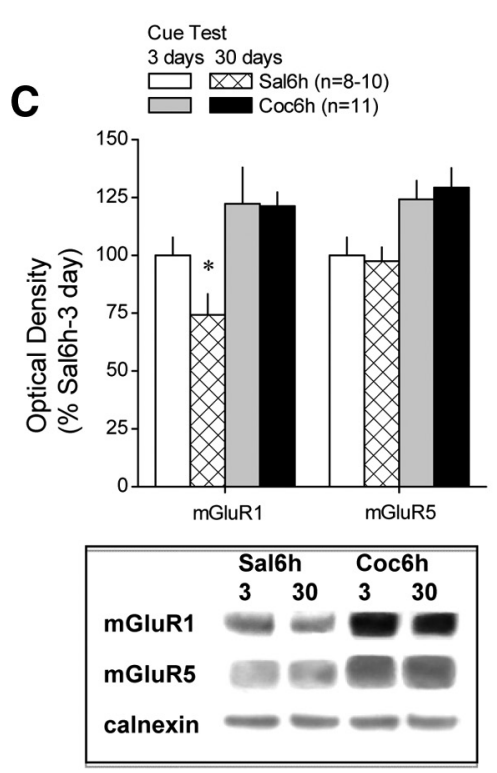

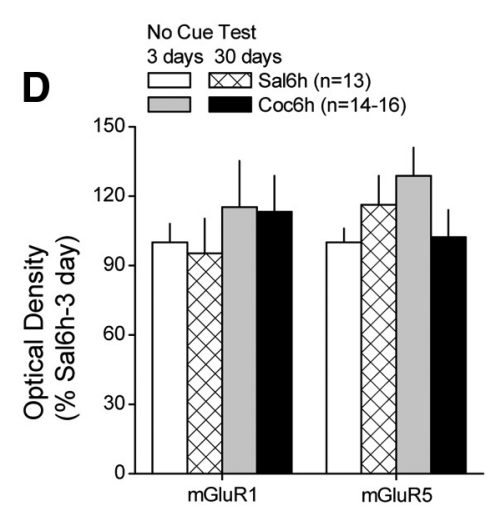

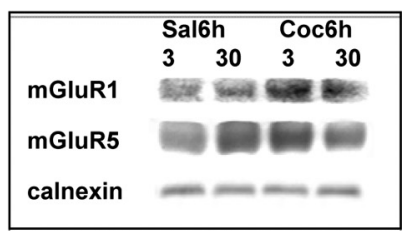

Figure 3. Differential effects of testing for cue-reinforced behavior on $\mathrm{mGluR} 1 / 5$ expression within $\mathrm{PFC}$ subregions during protracted withdrawal from self-administered cocaine. Immunoblotting for the change in total mGluR1 and mGluR5 protein expression within the VmPFC and dmPFC was conducted on tissue derived from saline- and cocaine-experienced animals tested for cue-reinforced behavior over a $2 \mathrm{~h}$ period (Cue Test) or left undisturbed in their home cages (No Cue Test) at 3 or $30 \mathrm{~d}$ after a $10 \mathrm{~d}$ history of extended access $(6 \mathrm{~h} / \mathrm{d})$ to either cocaine (Coc6h) or saline (Sal6h). Sample sizes ranged from 9 to 12 per group per withdrawal time point. $A$, A direct comparison of receptor protein expression within the vmPFC of Sal6h and Coc6h animals across the two withdrawal time points confirmed a time-dependent reduction in mGluR1/5 expression in Coc6h animals that were tested for cue-reinforced behavior before tissue harvest. $\boldsymbol{B}$, No statistically reliable change in vmPFC receptor expression was apparent in Coc6h rats that were not tested for cue-reinforced behavior before tissue collection. C, In contrast to the vmPFC, immunoblotting on $\mathrm{dmPFC}$ of these same animals revealed elevated receptor levels in Coc6h animals tested for cue-reinforced behavior at both 3

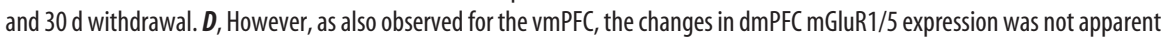
in animals left undisturbed before tissue harvest. Sample sizes are indicated in parentheses. ${ }^{*} p<0.05$ versus respective data at $3 \mathrm{~d}$ withdrawal.

across the two cue tests depended on the intracranial treatment of the animals (Fig. $5 \mathrm{~A}$ ) (intracranial group $\times$ test, $F_{(3,37)}=3.98$, $p=0.02$ ). Deconstruction of the significant interaction along the intracranial group factor revealed a test-dependent reduction in responding in rats infused intra-vmPFC with VEH before initial testing for cue-reinforced behavior $\left(F_{(1,10)}=9.17, p=0.01\right)$,

indicating extinction learning. Interestingly, cocaine-experienced rats infused intra-vmPFC with either MTEP or JNJ 16259685 before initial testing failed to show this test-dependent reduction in responding (respectively, $p=0.27$ and $p=0.61$ ), indicating impaired extinction learning or memory. In support of the latter possibility, cocaineexperienced animals infused intra-vmPFC with JNJ 16259685 immediately after the initial test also failed to exhibit a test-dependent reduction in lever-pressing behavior compared with controls $(p=0.45)$.

We also assayed the acute and residual effects of intra-dmPFC pretreatment with JNJ 16259685 on cue-reinforced responding at $3 \mathrm{~d}$ withdrawal. As illustrated in Figure $5 B$, acute pretreatment with the mGluR1 antagonist into the dmPFC failed to influence cue-reinforced behavior, nor did it alter the test-dependent reduction in behavior observed at $3 \mathrm{~d}$ withdrawal (test effect, $F_{(1,14)}=5.46, p=0.04$; intracranial effect and interaction, $p>0.90$ ).

\section{vmPFC group 1 mGluR stimulation} facilitates extinction learning after protracted withdrawal from cocaine Here again, no differences were observed for the average number of lever presses emitted for infusions of either saline or cocaine during self-administration training between the groups slated to receive intra-vmPFC VEH versus DHPG (Table 2) (intravenous effect, $F_{(1,45)}=66.15, p<$ 0.0001 ; no intracranial effect or interaction, $p$ values $>0.20$ ). Similar to the results for the antagonists, intra-vmPFC DHPG pretreatment failed to alter the behavior of saline-experienced animals, and all rats exhibited higher responding on the second test in the absence of any additional intracranial manipulation (Table 3) (test effect, $F_{(1,26)}=9.07, p=0.006$; intracranial effect and interaction, $p>0.17$ ). Replicating the data from our initial study (Fig. $5 B$ ), we failed to detect a significant acute effect of intra-vmPFC DHPG in cocaine-experienced animals on cuereinforced behavior at $30 \mathrm{~d}$ withdrawal. In fact, an analysis of the time course (in 5 min intervals) of lever-pressing behavior during the first cue test indicated that within-session extinction did not differ between VEH- and DHPG-pretreated cocaine-experienced rats (time effect, $F_{(5,70)}=11.67, p<0.0001$; time $\times$ intracranial interaction, $p>0.05)$. However, we observed differential effects of intra-vmPFC pretreatment on the change in behavior during subsequent testing (Fig. $5 C$ ) (test effect, $F_{(1,21)}=5.55, p=$ 0.03 ; intracranial effect, $p=0.62$; test $\times$ intracranial, $F_{(1,21)}=$ $6.15, p=002)$. As illustrated in Figure $5 C$, VEH-infused cocaine rats exhibited no change in behavior across the two cue tests 
Table 2. Comparison of the average number of infusions earned by saline ( $1 \mathrm{~h} / \mathrm{d}$; Sal $1 \mathrm{~h})$ and cocaine $(6 \mathrm{~h} / \mathrm{d}$; Coc $6 \mathrm{~h})$ self-administering rats during the last $3 \mathrm{~d}$ of selfadministration before studies of the effects of intra-vmPFC manipulations of group $1 \mathrm{mGluRs}$ at $3 \mathrm{~d}$ (antagonist studies) or $30 \mathrm{~d}$ (agonist study) withdrawal

\begin{tabular}{|c|c|c|c|c|}
\hline \multirow[b]{2}{*}{ Intracranial treatment } & \multicolumn{2}{|l|}{ Acute test } & \multicolumn{2}{|l|}{ Repeated testing } \\
\hline & Sal1h & Coc6h & Sal1h & Coc6h \\
\hline \multicolumn{5}{|l|}{$3 d$} \\
\hline VEH & $9.4 \pm 1.7(18)$ & $191.8 \pm 31.2(21)$ & $5.67 \pm 0.73(13)$ & $127.1 \pm 11.3(13)$ \\
\hline MPEP & $11.7 \pm 2.6(5)$ & $160.4 \pm 41.7(16)$ & & \\
\hline MTEP & & & $6.25 \pm 2.08(8)$ & $134.79 \pm 32.22(8)$ \\
\hline JNJ 16259685 pretreatment & $5.1 \pm 1.5(10)$ & $246.9 \pm 91.9(12)$ & $7.36 \pm 1.57(9)$ & $103.6 \pm 8.09(9)$ \\
\hline JNJ 16259685 posttreatment & & & & $110.8 \pm 6.3(13)$ \\
\hline dmPFC JNJ 16259685 & & & $108.1 \pm 14.2(6)$ & $91.7 \pm 4.5(8)$ \\
\hline \multicolumn{5}{|l|}{$30 d$} \\
\hline VEH & & $112.8 \pm 13.2(8)$ & $6.2 \pm 0.9(14)$ & $150.3 \pm 30.6(11)$ \\
\hline DHPG & & $109.6 \pm 11.4(9)$ & $4.5 \pm 0.6(12)$ & $115.0 \pm 12.8(9)$ \\
\hline
\end{tabular}

the statistical analysis of these data, as well as the cue test data presented in Figures 3 and 4

Table 3. Comparison of the average number of lever presses emitted by salineexperienced animals during tests for cue-reinforced behavior conducted at $3 \mathrm{~d}$ (antagonist studies) or $30 \mathrm{~d}$ (agonist study) after the last saline self-administration session

\begin{tabular}{lcll}
\hline & & \multicolumn{2}{l}{ Repeated testing } \\
\cline { 3 - 4 } Intracranial treatment & Acute test & Test 1 & Test 2 \\
\hline $3 \mathrm{~d}$ & & & \\
$\quad$ VEH & $6.1 \pm 1.3(18)$ & $2.92 \pm 0.9(13)$ & $8.2 \pm 1.6$ \\
$\quad$ MPEP & $5.8 \pm 1.9(5)$ & & \\
MTEP & $1.14 \pm 0.7(7)$ & $2.7 \pm 0.7(7)$ & $7.7 \pm 2.1$ \\
JNJ 16259685 & $1.9 \pm 0.6(10)$ & $1.0 \pm 0.6(9)$ & $6.6 \pm 2.3$ \\
$30 \mathrm{~d}$ & & & \\
$\quad$ VEH & & $9.8 \pm 1.9(13)$ & $12.8 \pm 2.0$ \\
DHPG & & $5.5 \pm 1.2(15)$ & $12.7 \pm 2.8$ \\
\hline
\end{tabular}

Numbers in parentheses indicate the final sample sizes used in the statistical analyses of these data.

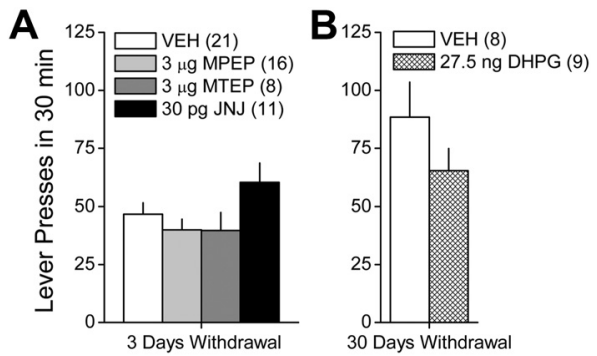

Figure 4. Intra-vmPFC pretreatment with mGluR-targeting compounds does not acutely influence cue-reinforced responding in cocaine-experienced animals. $A$, When assessed at $3 \mathrm{~d}$ withdrawal, an infusion of $3.0 \mu \mathrm{g} / \mathrm{side}$ of the mGluR5 antagonists MPEP or MTEP or $30 \mathrm{pg} / \mathrm{side}$ of the mGluR1 antagonist JNJ 16259685 (JNJ) failed to significantly influence cue-reinforced lever-pressing behavior exhibited by cocaine-experienced animals during a 30 min test of drug seeking. $\boldsymbol{B}$, Similarly, an infusion of $27.5 \mathrm{ng} /$ side of the $\mathrm{mGluR} 1 / 5$ agonist DHPG also failed to influence lever-pressing behavior when assessed in rats with a history of cocaine selfadministration at $30 \mathrm{~d}$ withdrawal. Sample sizes are indicated in parentheses.

$(p=0.90)$, indicating resistance to extinction during protracted withdrawal. In contrast, DHPG-infused cocaine rats exhibited an $\sim 30 \%$ reduction in lever pressing during subsequent testing, and this was statistically significant $\left(F_{(1,6)}=8.63, p=0.03\right)$.

\section{Discussion}

The present report provides validation of an important role for vmPFC group $1 \mathrm{mGluRs}$ in learning to suppress cocaine-seeking behavior during protracted withdrawal from heavy cocaine intake. Specifically, "incubated" drug-seeking and across-session extinction deficits exhibited by cocaine-experienced rats during protracted withdrawal were associated with reduced vmPFC
mGluR1/5 levels, which reflected an interaction between cocaine withdrawal and the opportunity to engage in cue-reinforced behavior under extinction conditions. Interestingly, intra-vmPFC manipulations of mGluR1/5 function had no immediate effects on cue-reinforced behavior under extinction conditions but produced residual effects on subsequent behavioral testing $24 \mathrm{~h}$ later. Intra-vmPFC mGluR1/5 blockade, either before or after testing for cue-reinforced behavior, impaired, whereas receptor hyperstimulation before testing facilitated, the manifestation of extinction learning in cocaine-experienced rats during short- and long-term withdrawal, respectively. In contrast, intra-dmPFC mGluR1 blockade failed to influence cue-reinforced behavior. Together, these results support the hypothesis that reduced vmPFC group $1 \mathrm{mGluR}$ function is a time-dependent adaptation that manifests when a heavily cocaine-experienced animal is given the opportunity to engage in drug seeking during withdrawal. This reduction in vmPFC group $1 \mathrm{mGluR}$ function impairs the ability to consolidate memories related to new behavior-outcome contingences in the absence of drug, rendering it more difficult to suppress drug craving and drug-seeking behavior when presented with stimuli predictive of drug availability.

\section{Cue-reinforced behavior and the regulation of PFC group 1 mGluR expression}

Alterations in PFC mGluR1/5 expression were observed only in cocaine-experienced animals allowed a single ( $2 \mathrm{~h}$ ) opportunity to engage in cue-reinforced behavior in the absence of cocaine. As reported previously (Ben-Shahar et al., 2009; Hao et al., 2010; Ghasemzadeh et al., 2011), we failed to detect changes in PFC group $1 \mathrm{mGluR}$ expression in cocaine-experienced animals left undisturbed in the home cage. Using procedures akin to those used in the present study, Ghasemzadeh et al. (2011) also failed to detect changes in either vmPFC or dmPFC mGluR 5 expression in cocaine-experienced animals withdrawn for $10 \mathrm{~d}$ in the absence of extinction training. However, they also failed to observe receptor changes within the vmPFC of animals with extensive $(10 \times$ 6-h sessions) extinction training but observed reduced mGluR5 levels within the dmPFC in behaviorally extinguished animals (Ghasemzadeh et al., 2011). Such data indicate that, akin to reports for $\mathrm{mPFC}$ AMPA glutamate receptors in heroinexperienced animals (Van den Oever et al., 2010), mGluR1/5 expression within both the vmPFC and dmPFC appears to be regulated in a complex manner by interactions between cocaine experience, duration of withdrawal, and the opportunity to engage in cue-reinforced behavior in the absence of cocaine. Furthermore, given the discrepancies in biochemical results between 


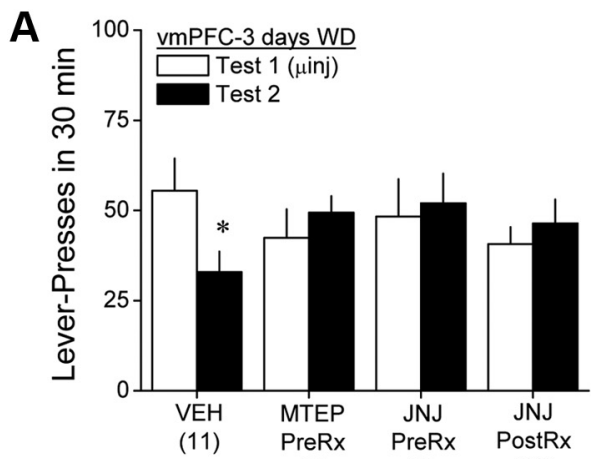

(8)

(13)

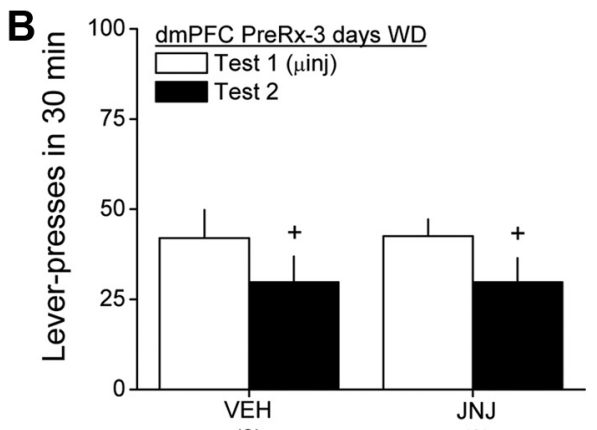

(8)

(8)

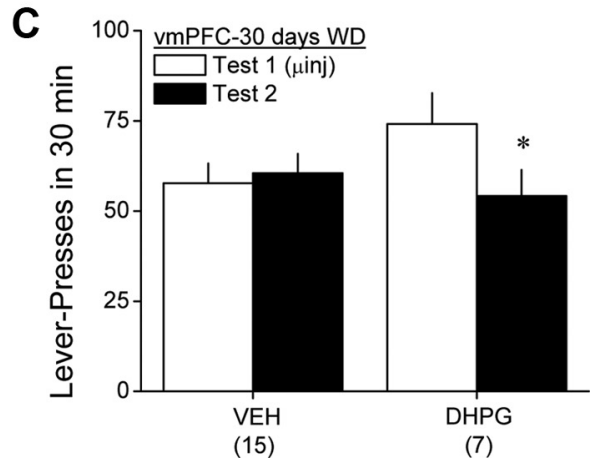

(15)

(7)

Figure 5. Intra-vmPFC pretreatment with mGluR-targeting compounds produces residual effects on cue-reinforced responding in cocaine-experienced animals. $\boldsymbol{A}$, When tested for cue-reinforced behavior $24 \mathrm{~h}$ after an intra-vmPFC infusion of $3.0 \mu \mathrm{g} /$ side MTEP before initial testing for cuereinforced behavior (MTEP PreRx) or an intra-vmPFC infusion of $30 \mathrm{pg} /$ side JNJ 16259685 either before (JNJPreRx) or immediately after (JNJ PostRx) the initial test for cue-reinforced behavior in the absence of any additional intracranial manipulation, VEH-pretreated rats exhibited reduced responding (extinction), whereas no behavioral extinction was apparent in animals pretreated or posttreated with mGluR antagonists. $\boldsymbol{B}$, In contrast to the vmPFC, intra-dmPFC pretreatment with $30 \mathrm{pg} / \mathrm{side} J \mathrm{NJ}$ 16259685 failed to influence behavioral extinction at $3 \mathrm{~d}$ withdrawal. $C$, Interestingly, when assayed at $30 \mathrm{~d}$ withdrawal, VEH-pretreated rats exhibited no sign of behavioral extinction when tested for cue-reinforced behavior, whereas extinction was facilitated in cocaine-experienced animals pretreated with $27 \mathrm{ng} /$ side DHPG. Sample sizes are indicated in parentheses. ${ }^{*} p<0.05$ versus test 1 . ${ }^{+} p<0.05$, main effect of test. WD, Withdrawal.

the present study $(1 \times 2$-h extinction session $)$ versus the previous study by Ghasemzadeh et al. $(2011)(10 \times 6$-h extinction sessions), it would appear that the effects of cocaine on mGluR1/5 expression within both the vmPFC and dmPFC depends also on the extent to which animals have undergone extinction training and/or manifest drug-seeking behavior, with vmPFC mGluR1/5 levels inversely related to drug seeking and $\mathrm{dmPFC}$ receptor levels positively related to drug seeking.

Group $1 \mathrm{mGluRs}$ undergo rapid desensitization involving receptor internalization and then degradation, and this develops tolerance on repeated receptor activation (Aronica et al.,

1993; Desai et al., 1995, 1996; Gereau and Heinemann, 1998). Thus, an incubation of cue-elicited glutamate release within the vmPFC might contribute not only to downregulated receptor expression observed within this subregion during initial extinction learning (present study) but also the apparent tolerance to this effect on extensive extinction training (Ghasemzadeh et al., 2011). At the present time, it is difficult to envision how a similar mechanism might be in place to regulate mGluR1/5 expression within $\mathrm{dmPFC}$ because receptor levels are increased in animals during initial extinction learning (present study) but decreased in behaviorally extinguished animals (Ghasemzadeh et al., 2011). It is not known whether or not cue-elicited glutamate release within PFC subregions varies as a function of cocaine experience/withdrawal. Because group $1 \mathrm{mGluRs}$ are perisynaptic in localization, future studies should focus on elucidating the relationship between subregional differences within PFC glutamate receptor expression and extracellular glutamate and how this relationship varies as a function of drug-related learning to begin to understand more precisely the mechanisms through which mGluR1/5 is differentially regulated within PFC subregions by the opportunity to engage in cue-reinforced behavior in the absence of cocaine.

\section{Neuropharmacological manipulations of vmPFC group 1 mGluRs and cue seeking}

Pharmacological manipulations of group $1 \mathrm{mGluR}$ function produced no obvious acute effects on cue-reinforced responding. Thus, neither vmPFC nor dmPFC group $1 \mathrm{mGluRs}$ play a major role in the cognitive, motivational, or motor capacity required to engage in cue-reinforced behavior or in the processes that underpin the expression of incubated cue-reinforced behavior during protracted withdrawal. To our knowledge, this study is the first to address the role for PFC group $1 \mathrm{mGluRs}$ during initial extinction of cocaine seeking. As such, we used doses of MPEP, MTEP, and JNJ 16259685 that are within the range of those demonstrated to maximally inhibit drug reward and/or reinforcement when infused intracranially in other animal models of drug seeking or drug taking, and the dose of DHPG used was at or above maximal for increasing locomotion and extracellular glutamate levels when infused into the brain (see Materials and Methods). The fact that we observed residual behavioral effects of our intravmPFC pretreatments argues against inadequate antagonist/agonist dosing as an explanation for our negative behavioral data. To date, all of the studies that have examined a potential role for group $1 \mathrm{mGluRs}$ in cue- or context-reinforced behavior have used animals with extensive extinction training, and typically, antagonist infusion into either the nucleus accumbens or hippocampus reduces cocaine seeking during cue/context reexposure (mGluR1: Dravolina et al., 2007; mGluR5: Bäckström et al., 2004; Bespalov et al., 2005; Schroeder et al., 2005; Gass and Olive, 2009b; Kumaresan et al., 2009; Martin-Fardon et al., 2009; Xie et al., 2010; Martin-Fardon and Weiss, 2011; Moussawi et al., 2011; Xie et al., 2012). Although there is some indication that prelimbic and infralimbic cortical inactivation influences drug-seeking behavior only in animals having undergone extinction training (McFarland and Kalivas, 2001; Capriles et al., 2003; Fuchs et al., 2006; Peters et al., 2008; but see Koya et al., 2009), the role of group 1 mGluRs within PFC subregions in drug seeking under extinction conditions remains to be examined. 


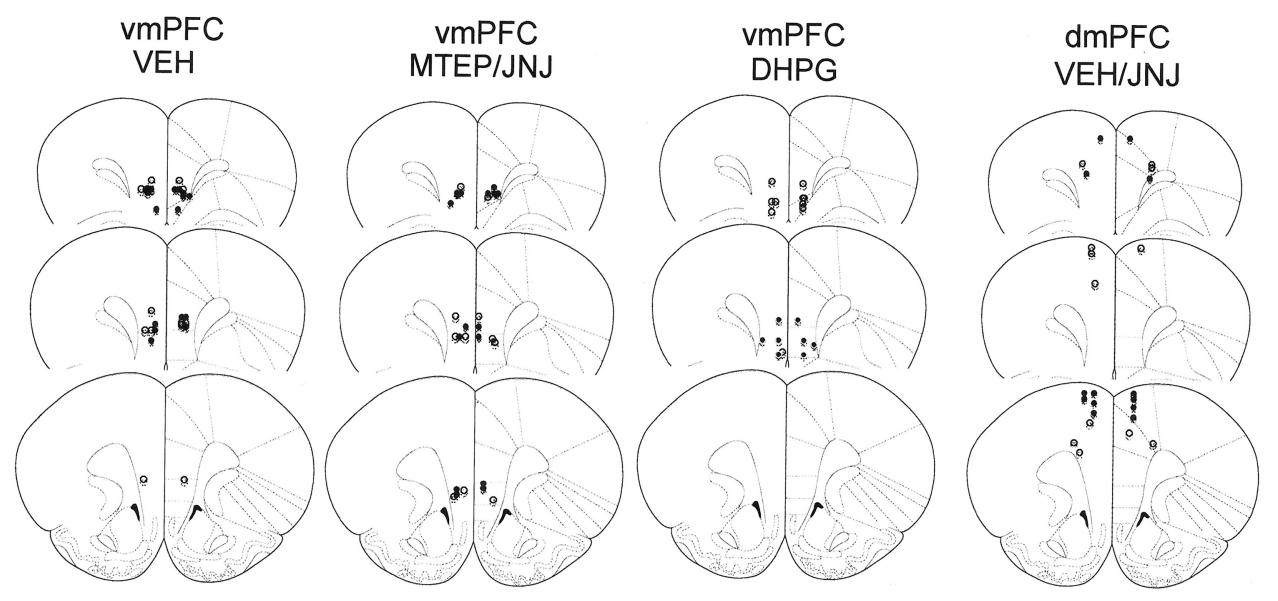

Figure 6. Histological verification of microinjector placements within the PFC. A diagram depicting the results of our histological examination of microinjector placements conducted on the completion of testing for the residual effects of an intra-VmPFC infusion of VEH, MTEP, JNJ 16259685 (JNJ), and DHPG and of an intra-dmPFC infusion of JNJ 16259685, as examples of placements for the animals included in the statistical analyses of the data in this study. As exemplified by the saline (open circles) and cocaine (filled circles) animals in this figure, only animals exhibiting microinjector placement within the ventral prelimbic cortex, within the infralimbic cortex or at their interface, were included in the statistical analyses of the data for vmPFC studies. As exemplified by the VEH (open circles) and JNJ 16259685 (filled circles) animals in the panel for the dmPFC study, only animals exhibiting microinjector placement within the dorsal prelimbic cortex, the anterior cingulate, or their interface were included in the statistical analyses of the data for the $\mathrm{dmPFC}$ study.

\section{Neuropharmacological manipulations of vmPFC group 1 mGluRs and behavioral extinction}

More ventral aspects of the PFC are posited to play a critical role in extinction of cocaine-seeking behavior (Schmidt et al., 2005; Peters et al., 2008; Hayton et al., 2010; Van den Oever et al., 2010), and there is an important glutamatergic component in this regard (Gass and Olive, 2009b; Hayton et al., 2010; Van den Oever et al., 2010; Millan et al., 2011). Consistent with this idea, dmPFC mGluR1 antagonist infusion failed to influence the manifestation of extinction learning during early withdrawal, whereas pharmacological manipulations of vmPFC mGluR1/5 function exerted extinction-modulating effects on the residual tests of cue-reinforced behavior. Mimicking the cocaine-induced reduction in vmPFC mGluR1/5 expression observed after protracted withdrawal was sufficient to elicit an extinction impairment akin to that exhibited by cocaineexperienced animals during protracted withdrawal. Interestingly, a similar MPEP-induced impairment of extinction of conditioned fear has been reported recently (Fontanez-Nuin et al., 2011) and is consistent with a general role of mGluR $1 / 5$ receptors in consolidation of learning (Riedel et al., 2003). Conversely, "rescuing" vmPFC group 1 mGluR function by high-dose DHPG infusion reversed the extinction deficit and reduced subsequent drug-seeking behavior exhibited by cocaine-experienced rats during protracted withdrawal. Overall, these data are consistent with recent demonstrations that systemic pretreatment with an mGluR5-positive allosteric modulator facilitates behavioral extinction and reduces drug-seeking behavior in cocaineexperienced animals (Cleva et al., 2011) and point to vmPFC group $1 \mathrm{mGluRs}$ as an important neural substrate in mediating these pro-cognitive and anti-addictive effects.

Electrophysiological and immunocytochemical evidence indicates that there is hyperactivation of vmPFC neurons by the behavior-contingent presentation of cocaine-paired cues early during extinction training in animals with a history of cocaine self-administration (Sun and Rebec, 2006; Koya et al., 2009). Particularly noteworthy are the parallel results for reduced vmPFC mGluR1/5 expression in the present study and elevated vmPFC levels of phospho-extracellular signalregulated kinase (ERK) reported by Koya et al. (2009) for cocaine-withdrawn rats assayed under very similar selfadministration and cue-reinforced testing conditions to those used in the present study. The inverse relationship between vmPFC group $1 \mathrm{mGluR}$ and phospho-ERK levels is intriguing in light of recent findings that group 1 mGluR stimulation, particularly mGluR1, augments inhibitory currents to a greater degree than excitatory currents within PFC (Sun and Neugebauer, 2011). Thus, although reduced mGluR $1 / 5$ expression may very well reflect a compensatory response to cue-elicited increases in vmPFC neuronal activity, such a reduction is predicted to disinhibit glutamatergic output from the vmPFC, a finding supported by a recent in vivo microdialysis study of animals responding for cocaine-paired cues without cocaine reinforcement (Suto et al., 2010). It follows then that the cue-elicited reduction in vmPFC mGluR1/5 expression observed during protracted withdrawal could very well instigate a feedforward mechanism of neuronal hyperexcitability within this structure that might be responsible for maintaining the saliency of drug-associated cues and the capacity of these cues to elicit drug craving even in protracted abstinence (Volkow et al., 1992; Childress et al., 1999; Goldstein and Volkow, 2002). Thus, the present data pose a time-dependent reduction in vmPFC mGluR $1 / 5$ expression as a molecular cordon to addiction recovery that best be overcome by receptor agonist, rather than antagonist, strategies.

\section{References}

Aronica E, Nicoletti F, Condorelli DF, Balázs R (1993) Pharmacological characterization of metabotropic glutamate receptors in cultured cerebellar granule cells. Neurochem Res 18:605-612. CrossRef Medline

Bäckström P, Hyyti ä P (2006) Ionotropic and metabotropic glutamate receptor antagonism attenuates cue-induced cocaine seeking. Neuropsychopharmacology 31:778-786. CrossRef Medline

Bäckström P, Hyyti ä P (2007) Involvement of AMPA/kainate, NMDA, and mGlu5 receptors in the nucleus accumbens core in cue-induced reinstatement of cocaine seeking in rats. Psychopharmacology 192:571-580. CrossRef Medline

Bäckström P, Bachteler D, Koch S, Hyytiä P, Spanagel R (2004) mGluR5 antagonist MPEP reduces ethanol-seeking and relapse behavior. Neuropsychopharmacology 29:921-928. CrossRef Medline

Ben-Shahar O, Ettenberg A (1998) Amphetamine infusions into the prefrontal cortex attenuate the sensitization to amphetamine. Prog Neuropsychopharmacol Biol Psychiatry 22:763-773. CrossRef Medline 
Ben-Shahar O, Ahmed SH, Koob GF, Ettenberg A (2004) The transition from controlled to compulsive drug use is associated with a loss of sensitization. Brain Res 995:46-54. CrossRef Medline

Ben-Shahar O, Posthumus EJ, Waldroup SA, Ettenberg A (2008) Heightened drug-seeking motivation following extended daily access to self-administered cocaine. Prog Neuropsychopharmacol Biol Psychiatry 32:863-869. CrossRef Medline

Ben-Shahar O, Obara I, Ary AW, Ma N, Mangiardi MA, Medina RL, Szumlinski KK (2009) Extended daily access to cocaine results in distinct alterations in Homer 1b/c and NMDA receptor subunit expression within the medial prefrontal cortex. Synapse 63:598-609. CrossRef Medline

Ben-Shahar OM, Szumlinski KK, Lominac KD, Cohen A, Gordon E, Ploense KL, Demartini J, Bernstein N, Rudy NM, Nabhan AN, Sacramento A, Pagano K, Carosso GA, Woodward N (2012) Extended access to cocaine self-administration results in reduced glutamate function within the medial prefrontal cortex. Addict Biol 17:746-757. CrossRef Medline

Bespalov AY, Dravolina OA, Sukhanov I, Zakharova E, Blokhina E, Zvartau E, Danysz W, van Heeke G, Markou A (2005) Metabotropic glutamate receptor (mGluR5) antagonist MPEP attenuated cue- and scheduleinduced reinstatement of nicotine self-administration behavior in rats. Neuropharmacology 49 [Suppl 1]:167-178. CrossRef Medline

Bonson KR, Grant SJ, Contoreggi CS, Links JM, Metcalfe J, Weyl HL, Kurian V, Ernst M, London ED (2002) Neural systems and cue-induced cocaine craving. Neuropsychopharmacology 26:376-386. CrossRef Medline

Capriles N, Rodaros D, Sorge RE, Stewart J (2003) A role for the prefrontal cortex in stress- and cocaine-induced reinstatement of cocaine seeking in rats. Psychopharmacology 168:66-74. CrossRef Medline

Chiamulera C, Epping-Jordan MP, Zocchi A, Marcon C, Cottiny C, Tacconi S, Corsi M, Orzi F, Conquet F (2001) Reinforcing and locomotor stimulant effects of cocaine are absent in mGluR5 null mutant mice. Nat Neurosci 4:873-874. CrossRef Medline

Childress AR, Mozley PD, McElgin W, Fitzgerald J, Reivich M, O'Brien CP (1999) Limbic activation during cue-induced cocaine craving. Am J Psychiatry 156:11-18. Medline

Childress AR, Ehrman RN, Wang Z, Li Y, Sciortino N, Hakun J, Jens W, Suh J, Listerud J, Marquez K, Franklin T, Langleben D, Detre J, O'Brien CP (2008) Prelude to passion: limbic activation by "unseen" drug and sexual cues. PLoS One 3:e1506. CrossRef Medline

Ciccocioppo R, Sanna PP, Weiss F (2001) Cocaine-predictive stimulus induces drug-seeking behavior and neural activation in limbic brain regions after multiple months of abstinence: reversal by $\mathrm{D}(1)$ antagonists. Proc Natl Acad Sci U S A 98:1976-1981. CrossRef Medline

Clark L, Cools R, Robbins TW (2004) The neuropsychology of ventral prefrontal cortex: decision-making and reversal learning. Brain Cogn 55:41-53. CrossRef Medline

Cleva RM, Hicks MP, Gass JT, Wischerath KC, Plasters ET, Widholm JJ, Olive MF (2011) mGluR5 positive allosteric modulation enhances extinction learning following cocaine self-administration. Behav Neurosci 125:10-19. CrossRef Medline

Cozzoli DK, Goulding SP, Zhang PW, Xiao B, Hu JH, Ary AW, Obara I, Rahn A, Abou-Ziab H, Tyrrel B, Marini C, Yoneyama N, Metten P, Snelling C, Dehoff MH, Crabbe JC, Finn DA, Klugmann M, Worley PF, Szumlinski KK (2009) Binge drinking upregulates accumbens mGluR5-Homer2-PI3K signaling: functional implications for alcoholism. J Neurosci 29:8655-8668. CrossRef Medline

Cozzoli DK, Courson J, Caruana AL, Miller BW, Greentree DI, Thomspon AB, Wroten MG, Zhang PW, Xiao B, Hu JH, Klugmann M, Metten P, Worley PF, Crabbe JC, Szumlinski KK (2012) Nucleus accumbens mGluR5-associated signaling regulates binge alcohol drinking under drinking-in-the-dark procedures. Alcohol Clin Exp Res 36:1623-1633. CrossRef Medline

Damasio AR (1996) The somatic marker hypothesis and the possible functions of the prefrontal cortex. Philos Trans R Soc Lond B Biol Sci 351: 1413-1420. CrossRef Medline

Desai MA, Burnett JP, Mayne NG, Schoepp DD (1995) Cloning and expression of a human metabotropic glutamate receptor 1 alpha: enhanced coupling on co-transfection with a glutamate transporter. Mol Pharmacol 48:648-657. Medline

Desai MA, Burnett JP, Mayne NG, Schoepp DD (1996) Pharmacological characterization of desensitization in a human mGlul alpha-expressing non-neuronal cell line co-transfected with a glutamate transporter. $\mathrm{Br} \mathrm{J}$ Pharmacol 118:1558-1564. CrossRef Medline
Dravolina OA, Zakharova ES, Shekunova EV, Zvartau EE, Danysz W, Bespalov AY (2007) mGlul receptor blockade attenuates cue- and nicotineinduced reinstatement of extinguished nicotine self-administration behavior in rats. Neuropharmacology 52:263-269. CrossRef Medline

Fontanez-Nuin DE, Santini E, Quirk GJ, Porter JT (2011) Memory for fear extinction requires mGluR5-mediated activation of infralimbic neurons. Cereb Cortex 21:727-735. CrossRef Medline

Franklin TR, Acton PD, Maldjian JA, Gray JD, Croft JR, Dackis CA, O'Brien CP, Childress AR (2002) Decreased gray matter concentration in the insular, orbitofrontal, cingulate, and temporal cortices of cocaine patients. Biol Psychiatry 51:134-142. CrossRef Medline

Fuchs RA, Evans KA, Ledford CC, Parker MP, Case JM, Mehta RH, See RE (2005) The role of the dorsomedial prefrontal cortex, basolateral amygdala, and dorsal hippocampus in contextual reinstatement of cocaine seeking in rats. Neuropsychopharmacology 30:296-309. CrossRef Medline

Fuchs RA, Branham RK, See RE (2006) Different neural substrates mediate cocaine seeking after abstinence versus extinction training: a critical role for the dorsolateral caudate-putamen. J Neurosci 26:3584-3588. CrossRef Medline

Garavan H, Pankiewicz J, Bloom A, Cho JK, Sperry L, Ross TJ, Salmeron BJ, Risinger R, Kelley D, Stein EA (2000) Cue-induced cocaine craving: neuroanatomical specificity for drug users and drug stimuli. Am J Psychiatry 157:1789-1798. CrossRef Medline

Gass JT, Olive MF (2009a) Role of protein kinase C epsilon (PKCvarepsilon) in the reduction of ethanol reinforcement due to mGluR5 antagonism in the nucleus accumbens shell. Psychopharmacology 204:587-597. CrossRef Medline

Gass JT, Olive MF (2009b) Positive allosteric modulation of mGluR5 receptors facilitates extinction of a cocaine contextual memory. Biol Psychiatry 65:717-720. CrossRef Medline

Gereau RW 4th, Heinemann SF (1998) Role of protein kinase C phosphorylation in rapid desensitization of metabotropic glutamate receptor 5 . Neuron 20:143-151. CrossRef Medline

Ghasemzadeh MB, Vasudevan P, Mueller C (2009) Locomotor sensitization to cocaine is associated with distinct pattern of glutamate receptor trafficking to the postsynaptic density in prefrontal cortex: early versus late withdrawal effects. Pharmacol Biochem Behav 92:383-392. CrossRef Medline

Ghasemzadeh MB, Vasudevan P, Giles C, Purgianto A, Seubert C, Mantsch JR (2011) Glutamatergic plasticity in medial prefrontal cortex and ventral tegmental area following extended-access cocaine self-administration. Brain Res 1413:60-71. CrossRef Medline

Goldstein RZ, Volkow ND (2002) Drug addiction and its underlying neurobiological basis: neuroimaging evidence for the involvement of the frontal cortex. Am J Psychiatry 159:1642-1652. CrossRef Medline

Goldstein RZ, Alia-Klein N, Tomasi D, Carrillo JH, Maloney T, Woicik PA, Wang R, Telang F, Volkow ND (2009a) Anterior cingulate cortex hypoactivations to an emotionally salient task in cocaine addiction. Proc Natl Acad Sci U S A 106:9453-9458. CrossRef Medline

Goldstein RZ, Craig AD, Bechara A, Garavan H, Childress AR, Paulus MP, Volkow ND (2009b) The neurocircuitry of impaired insight in drug addiction. Trends Cogn Sci 13:372-380. CrossRef Medline

Goulding SP, Obara I, Lominac KD, Gould AT, Miller BW, Klugmann M, Szumlinski KK (2011) Accumbens Homer2-mediated signaling: a factor contributing to mouse strain differences in alcohol drinking? Genes Brain Behav 10:111-126. CrossRef Medline

Grant S, London ED, Newlin DB, Villemagne VL, Liu X, Contoreggi C, Phillips RL, Kimes AS, Margolin A (1996) Activation of memory circuits during cue-elicited cocaine craving. Proc Natl Acad Sci U S A 93:12040-12045. CrossRef Medline

Grimm JW, Hope BT, Wise RA, Shaham Y (2001) Neuroadaptation. Incubation of cocaine craving after withdrawal. Nature 412:141-142. CrossRef Medline

Grimm JW, Shaham Y, Hope BT (2002) Effect of cocaine and sucrose withdrawal period on extinction behavior, cue-induced reinstatement, and protein levels of the dopamine transporter and tyrosine hydroxylase in limbic and cortical areas in rats. Behav Pharmacol 13:379-388. CrossRef Medline

Hamlin AS, Clemens KJ, McNally GP (2008) Renewal of extinguished cocaine-seeking. Neuroscience 151:659-670. CrossRef Medline

Hao Y, Martin-Fardon R, Weiss F (2010) Behavioral and functional evi- 
dence of metabotropic glutamate receptor $2 / 3$ and metabotropic glutamate receptor 5 dysregulation in cocaine-escalated rats: factor in the transition to dependence. Biol Psychiatry 68:240-248. CrossRef Medline

Hayton SJ, Lovett-Barron M, Dumont EC, Olmstead MC (2010) Targetspecific encoding of response inhibition: increased contribution of AMPA to NMDA receptors at excitatory synapses in the prefrontal cortex. J Neurosci 30:11493-11500. CrossRef Medline

Hearing MC, See RE, McGinty JF (2008) Relapse to cocaine-seeking increases activity-regulated gene expression differentially in the striatum and cerebral cortex of rats following short or long periods of abstinence. Brain Struct Funct 213:215-227. CrossRef Medline

Iso Y, Grajkowska E, Wroblewski JT, Davis J, Goeders NE, Johnson KM, Sanker S, Roth BL, Tueckmantel W, Kozikowski AP (2006) Synthesis and structure-activity relationships of 3-[(2-methyl-1,3-thiazol-4yl)ethynyl]pyridine analogues as potent, noncompetitive metabotropic glutamate receptor subtype 5 antagonists; search for cocaine medications. J Med Chem 49:1080-1100. CrossRef Medline

Kalivas PW, O'Brien C (2008) Drug addiction as a pathology of staged neuroplasticity. Neuropsychopharmacology 33:166-180. CrossRef Medline

Kenny PJ, Markou A (2004) The ups and downs of addiction: role of metabotropic glutamate receptors. Trends Pharmacol Sci 25:265-272. CrossRef Medline

Kerstetter KA, Aguilar VR, Parrish AB, Kippin TE (2008) Protracted timedependent increases in cocaine-seeking behavior during cocaine withdrawal in female relative to male rats. Psychopharmacology 198:63-75. CrossRef Medline

Konishi S, Nakajima K, Uchida I, Sekihara K, Miyashita Y (1998) No-go dominant brain activity in human inferior prefrontal cortex revealed by functional magnetic resonance imaging. Eur J Neurosci 10:1209-1213. CrossRef Medline

Koya E, Uejima JL, Wihbey KA, Bossert JM, Hope BT, Shaham Y (2009) Role of ventral medial prefrontal cortex in incubation of cocaine craving. Neuropharmacology 56 [Suppl 1]:177-185. CrossRef Medline

Kumaresan V, Yuan M, Yee J, Famous KR, Anderson SM, Schmidt HD, Pierce RC (2009) Metabotropic glutamate receptor 5 (mGluR5) antagonists attenuate cocaine priming- and cue-induced reinstatement of cocaine seeking. Behav Brain Res 202:238-244. CrossRef Medline

London ED, Ernst M, Grant S, Bonson K, Weinstein A (2000) Orbitofrontal cortex and human drug abuse: functional imaging. Cereb Cortex 10:334-342. CrossRef Medline

Martin-Fardon R, Weiss F (2011) (-)-2-oxa-4-aminobicylco[3.1.0] hexane4,6-dicarboxylic acid (LY379268) and 3-[(2-methyl-1,3-thiazol-4-yl)ethynyl]piperidine (MTEP) similarly attenuate stress-induced reinstatement of cocaine seeking. Addict Biol. Advance online publication. Retrieved November 19, 2012. doi:10.1111/j.1369-1600.2011.00345.x. CrossRef Medline

Martin-Fardon R, Baptista MA, Dayas CV, Weiss F (2009) Dissociation of the effects of MTEP [3-[(2-methyl-1,3-thiazol-4-yl)ethynyl]piperidine] on conditioned reinstatement and reinforcement: comparison between cocaine and a conventional reinforcer. J Pharmacol Exp Ther 329:1084-1090. CrossRef Medline

Matochik JA, London ED, Eldreth DA, Cadet JL, Bolla KI (2003) Frontal cortical tissue composition in abstinent cocaine abusers: a magnetic resonance imaging study. Neuroimage 19:1095-1102. CrossRef Medline

McFarland K, Kalivas PW (2001) The circuitry mediating cocaine-induced reinstatement of drug-seeking behavior. J Neurosci 21:8655-8663. Medline

McLaughlin J, See RE (2003) Selective inactivation of the dorsomedial prefrontal cortex and the basolateral amygdala attenuates conditioned-cued reinstatement of extinguished cocaine-seeking behavior in rats. Psychopharmacology 168:57-65. CrossRef Medline

Melendez RI, Vuthiganon J, Kalivas PW (2005) Regulation of extracellular glutamate in the prefrontal cortex: focus on the cystine-glutamate exchanger and group I metabotropic glutamate receptors. J Pharmacol Exp Ther 314:139-147. CrossRef Medline

Millan EZ, Marchant NJ, McNally GP (2011) Extinction of drug seeking. Behav Brain Res 217:454-462. CrossRef Medline

Moussawi K, Zhou W, Shen H, Reichel CM, See RE, Carr DB, Kalivas PW (2011) Reversing cocaine-induced synaptic potentiation provides enduring protection from relapse. Proc Natl Acad Sci U S A 108:385-390. CrossRef Medline

Neisewander JL, Baker DA, Fuchs RA, Tran-Nguyen LT, Palmer A, Marshall JF (2000) Fos protein expression and cocaine-seeking behavior in rats after exposure to a cocaine self- administration environment. J Neurosci 20:798-805. Medline

O'Brien CP (2009) Neuroplasticity in addictive disorders. Dialogues Clin Neurosci 11:350-353. Medline

Olive MF (2010) Cognitive effects of Group I metabotropic glutamate receptor ligands in the context of drug addiction. Eur J Pharmacol 639:47-58. CrossRef Medline

Paxinos G, Watson C (2007) The rat brain in stereotaxic coordinates, Ed 6. London: Academic.

Peters J, LaLumiere RT, Kalivas PW (2008) Infralimbic prefrontal cortex is responsible for inhibiting cocaine seeking in extinguished rats. J Neurosci 28:6046-6053. CrossRef Medline

Riedel G, Platt B, Micheau J (2003) Glutamate receptor function in learning and memory. Behav Brain Res 140:1-47. CrossRef Medline

Robinson TE, Gorny G, Mitton E, Kolb B (2001) Cocaine selfadministration alters the morphology of dendrites and dendritic spines in the nucleus accumbens and neocortex. Synapse 39:257-266. CrossRef Medline

Rolls ET, Hornak J, Wade D, McGrath J (1994) Emotion-related learning in patients with social and emotional changes associated with frontal lobe damage. J Neurol Neurosurg Psychiatry 57:1518-1524. CrossRef Medline

Schmidt ED, Voorn P, Binnekade R, Schoffelmeer AN, De Vries TJ (2005) Differential involvement of the prelimbic cortex and striatum in conditioned heroin and sucrose seeking following long-term extinction. Eur J Neurosci 22:2347-2356. CrossRef Medline

Schroeder JP, Overstreet DH, Hodge CW (2005) The mGluR5 antagonist MPEP decreases operant ethanol self-administration during maintenance and after repeated alcohol deprivations in alcohol-preferring $(\mathrm{P})$ rats. Psychopharmacology 179:262-270. CrossRef Medline

Sun H, Neugebauer V (2011) mGluR1, but not mGluR5, activates feedforward inhibition in the medial prefrontal cortex to impair decision making. J Neurophysiol 106:960-973. CrossRef Medline

Sun W, Rebec GV (2006) Repeated cocaine self-administration alters processing of cocaine-related information in rat prefrontal cortex. J Neurosci 26:8004-8008. CrossRef Medline

Suto N, Ecke LE, You ZB, Wise RA (2010) Extracellular fluctuations of dopamine and glutamate in the nucleus accumbens core and shell associated with lever-pressing during cocaine self-administration, extinction, and yoked cocaine administration. Psychopharmacology 211:267-275. CrossRef Medline

Swanson CJ, Kalivas PW (2000) Regulation of locomotor activity by metabotropic glutamate receptors in the nucleus accumbens and ventral tegmental area. J Pharmacol Exp Ther 292:406-414. Medline

Swanson CJ, Baker DA, Carson D, Worley PF, Kalivas PW (2001) Repeated cocaine administration attenuates group I metabotropic glutamate receptor-mediated glutamate release and behavioral activation: a potential role for Homer. J Neurosci 21:9043-9052. Medline

Szumlinski KK, Dehoff MH, Kang SH, Frys KA, Lominac KD, Klugmann M, Rohrer J, Griffin W 3rd, Toda S, Champtiaux NP, Berry T, Tu JC, Shealy SE, During MJ, Middaugh LD, Worley PF, Kalivas PW (2004) Homer proteins regulate sensitivity to cocaine. Neuron. 43:401-413. CrossRef Medline

Tang W, Wesley M, Freeman WM, Liang B, Hemby SE (2004) Alterations in ionotropic glutamate receptor subunits during binge cocaine selfadministration and withdrawal in rats. J Neurochem 89:1021-1033. CrossRef Medline

Tran-Nguyen LT, Fuchs RA, Coffey GP, Baker DA, O’Dell LE, Neisewander JL (1998) Time-dependent changes in cocaine-seeking behavior and extracellular dopamine levels in the amygdala during cocaine withdrawal. Neuropsychopharmacology 19:48-59. CrossRef Medline

Uys JD, LaLumiere RT (2008) Glutamate: the new frontier in pharmacotherapy for cocaine addiction. CNSNeurol Disord Drug Targets 7:482-491. CrossRef Medline

Van den Oever MC, Spijker S, Smit AB, De Vries TJ (2010) Prefrontal cortex plasticity mechanisms in drug seeking and relapse. Neurosci Biobehav Rev 35:276-284. CrossRef Medline

Volkow ND, Hitzemann R, Wang GJ, Fowler JS, Wolf AP, Dewey SL, Handlesman L (1992) Long-term frontal brain metabolic changes in cocaine abusers. Synapse 11:184-190. CrossRef Medline

Volkow ND, Fowler JS, Wang GJ, Hitzemann R, Logan J, Schlyer DJ, Dewey SL, Wolf AP (1993) Decreased dopamine D2 receptor availability is as- 
sociated with reduced frontal metabolism in cocaine abusers. Synapse 14:169-177. CrossRef Medline

Volkow ND, Wang GJ, Fowler JS, Hitzemann R, Angrist B, Gatley SJ, Logan J, Ding YS, Pappas N (1999) Association of methylphenidate-induced craving with changes in right striato-orbitofrontal metabolism in cocaine abusers: implications in addiction. Am J Psychiatry 156:19-26. Medline

Xie X, Ramirez DR, Lasseter HC, Fuchs RA (2010) Effects of mGluR1 antagonism in the dorsal hippocampus on drug context-induced reinstatement of cocaine-seeking behavior in rats. Psychopharmacology 208:1-11. CrossRef Medline

Xie X, Lasseter HC, Ramirez DR, Ponds KL, Wells AM, Fuchs RA (2012) Subregion-specific role of glutamate receptors in the nucleus accumbens on drug context-induced reinstatement of cocaine-seeking behavior in rats. Addict Biol 17:287-299. CrossRef Medline

Zavala AR, Osredkar T, Joyce JN, Neisewander JL (2008) Upregulation of Arc mRNA expression in the prefrontal cortex following cueinduced reinstatement of extinguished cocaine-seeking behavior. Synapse 62:421-431. CrossRef Medline

Zayara AE, McIver G, Valdivia PN, Lominac KD, McCreary AC, Szumlinski KK (2011) Blockade of nucleus accumbens 5-HT2A and 5-HT2C receptors prevents the expression of cocaine-induced behavioral and neurochemical sensitization in rats. Psychopharmacology 213:321-335. CrossRef Medline 